Research article

\title{
Physiological highlights of manganese toxicity symptoms in soybean plants: Mn toxicity responses
}

\author{
Elcio Ferreira Santos a , José Mateus Kondo Santini ${ }^{\mathrm{b}}$, Amanda Pereira Paixão ${ }^{\mathrm{b}}$, \\ Enes Furlani Júnior ${ }^{b}$, José Lavres ${ }^{a}$, Marcelo Campos ${ }^{c}$, André Rodrigues dos Reis ${ }^{b}, c, *$ \\ ${ }^{a}$ USP - University of São Paulo, Center for Nuclear Energy in Agriculture, Postal Code 13416-000, Piracicaba, SP, Brazil \\ ${ }^{\mathrm{b}}$ UNESP - São Paulo State University, Postal Code 15385-000, Ilha Solteira, SP, Brazil \\ ${ }^{c}$ UNESP - São Paulo State University, Postal Code 17602-496, Tupã, SP, Brazil
}

\section{A R T I C L E I N F O}

\section{Article history:}

Received 12 December 2016

Received in revised form

24 January 2017

Accepted 24 January 2017

Available online 25 January 2017

\section{Keywords:}

Antioxidative stress

Gas exchange parameters

Energy-dispersive X-ray spectroscopy

Manganese phytotoxicity

Mineral plant nutrition

\begin{abstract}
A B S T R A C T
Manganese (Mn) is an essential element for plants; however, high concentrations in certain soil conditions can cause toxicity symptoms in the plant tissue. Here, we describe Mn toxicity symptoms and Mn toxicity responses in soybean plants. Soybean plants exposed to excess $\mathrm{Mn}$ showed reductions in the $\mathrm{CO}_{2}$ assimilation rate and stomatal conductance, which in turn resulted in decreased shoot biomass. Furthermore, peroxidase (POD), superoxide dismutase (SOD), and catalase (CAT) activity were higher in plants grown with the highest Mn concentration. The Mn doses increased the activity of antioxidant enzymes such as CAT, POD, and SOD. The toxicity symptoms presented by the leaves included hypertrophying of the adaxial epidermis and the formation of necrotic areas with purple-colored veins. Dramatic movement of calcium from the healthy region to the purple-colored necrotic region was observed, as was the exit of potassium from the necrotic area to the healthy region of the tissue. The high activities of POD and SOD in the presence of high Mn compartmented in the roots was the main physiological responses at high Mn uptake by soybean plants.
\end{abstract}

๑) 2017 Elsevier Masson SAS. All rights reserved.

\section{Introduction}

Manganese (Mn) is an essential element in plants that participates in protein structure and phosphorylation enzymes. Its deficiency causes damage to chloroplasts, affecting the water photolysis in photosystem II, which supplies the electrons necessary for photosynthesis (Fernando and Lynch, 2015). However, its excess is also harmful because of toxicity to plants. The toxicity

Abbreviations: $A, \mathrm{CO}_{2}$ assimilation rate; $C_{1}$, capacity of internal carbon use; ABET, epidermal thickness of the lower or abaxial face; ADET, epidermal thickness of the upper or adaxial face; CAT, catalase; $E$, transpiration; EDS, energy-dispersive X-ray spectroscopy; gs, stomatal conductance; LPD, leaf phloem diameter; LXD, leaf xylem diameter; PAR, photosynthetically active radiation; POD, peroxidase; RET, root epidermis thickness; ROS, reactive oxygen species; RPD, root phloem diameter; RXD, root xylem diameter; SOD, superoxide dismutase.

* Corresponding author. UNESP - São Paulo State University, Postal Code 17602496, Tupã, SP, Brazil.

E-mail addresses: elciokw@yahoo.com.br (E.F. Santos), santinijmk@gmail.com (J.M. Kondo Santini), amandappaixao@yahoo.com.br (A.P. Paixão), enes@agr.feis. unesp.br (E.F. Júnior), jlavres@usp.br (J. Lavres), marcelocampos@tupa.unesp.br (M. Campos), andrereis@tupa.unesp.br (A.R. Reis). limit of Mn, as well as tolerance to excesses of this metal, is dependent on the plant species, in addition to varieties or genotypes (Kochian et al., 2004; Ducic and Polle, 2005). However, its toxicity is favored in acidic soils (Fageria and Stone, 2008).

Excessive concentrations of $\mathrm{Mn}$ in plant tissues may alter various processes, such as enzymatic activity, uptake, redistribution, and the use of other nutrients ( $\mathrm{Ca}, \mathrm{Fe}, \mathrm{Mg}, \mathrm{N}$ and $\mathrm{P}$ ), in addition to the productive responses of agricultural crops (Lavres Junior et al., 2010). The literature has reported that toxicity by metals e.g., $\mathrm{Mn}$ - induces oxidative stress (St. Clair and Lynch, 2005; St. Clair et al., 2005). However, the antioxidative system response to this stress presents variable and controversial results (Schutzendubel and Polle, 2002; Gratão et al., 2005; Gill and Tuteja, 2010). There are several factors responsible for this lack of consensus: heavy metals that exert different stress induction mechanisms; compartmentalization of antioxidants, leading to differences between responses among the organelles, cells, and tissues; and the detoxification and complexation of heavy metals reducing its stimulating effects on oxidative stress (Gratão et al., 2005). This lack of consensus emphasizes the need for further studies describing the toxicity of different metals, such as $\mathrm{Mn}$, 
because there is minimal description of its modification to the antioxidative system as a function of its toxicity.

The toxicity caused by Mn results in the degradation of lipids, proteins, carbohydrates, and nucleic acids, damaging the cell metabolism and causing cell death in some cases (Fernando et al., 2013). Plants signal Mn toxicity by means of receptors that trigger molecular signal cascades that transmit the signals to the regulating systems via ion channels, signaling proteins, and second messenger compounds (Schmutz et al., 2010; Choudhary et al., 2012; Le et al., 2012). Mn toxicity can also influence photosynthesis; however, there is a lack of specific information on this topic. Previous studies have indicated that during heavy metal stress, the energized electrons are allocated to oxygen (Toth et al., 2011; Fischer et al., 2015). Furthermore, a lower availability of oxygen reduces the efficiency of the electron transport chain; hence, less $\mathrm{NADP}^{+}$is reduced, which decreases the $\mathrm{CO}_{2}$ fixation rate (Foyer and Shigeoka, 2011; Gururani et al., 2015).

Effects on the decrease of the photosynthesis rate by Mn toxicity were reported by Weng et al. (2013) and Rojas-Lillo et al. (2014), who attributed degradation of the photosynthetic apparatus in the chloroplasts as the cause. When working with Phytolacca acinosa (hyperaccumulator species of Mn), Weng et al. (2013) reported little effect of the toxic Mn supply on photosynthetic activity, attributing the Mn hyperaccumulator capacity of the species to efficient Mn complexing and not to abruptly modifying the chloroplast structures. Undoubtedly, upon degradation of the photosynthetic apparatus, such as through the stress effect caused by toxicity, one can expect a direct effect on the growth and development of the cultures.

Studies on the Mn toxicity effect on soybeans are scarce in the literature; consequently, it is unknown how Mn toxicity can influence the development of the culture, knowing that in Brazil this culture is highly produced in the Cerrado region (similar to savannas), where soils with high Mn contents are easily found (Fageria and Stone, 2008). The present study hypothesizes that the soybean responses mechanism to excess $\mathrm{Mn}$ is a direct result of greater partitioning of the element in the roots in conjunction with enzyme expression of the antioxidant system in the roots and/or shoots - as a second barrier if there is no retention in the roots. Based on the above information, the present study sought to evaluate responses mechanisms and characterize Mn toxicity symptoms in soybean plants by physiological, biochemical, and ultrastructural analyses, as well as through energy-dispersive X-ray spectroscopy (EDS) techniques for studies on the localization of Mn and other nutrients in the cells of plant tissue.

\section{Materials and methods}

\subsection{Growth conditions and experimental design}

Soybean seeds of the variety BMX Potência RR were germinated in plastic pots with vermiculite. Uniform young seedlings at 21 days after sowing were washed with deionized water and transplanted in 6-L polyethylene pots containing nutrient solution with $25 \%$ ionic strength not containing Mn Hoagland and Arnon (1950). After 5 days of plant adaptation in the nutrient solution, Mn treatments of 0 (deficient), $2,10,100,200$, and $300 \mu \mathrm{mol} \mathrm{L}^{-1}$, with $100 \%$ ionic strength of the nutrient solution were applied. The nutrient solution containing $2 \mu \mathrm{mol} \mathrm{L} \mathrm{L}^{-1}$ of $\mathrm{Mn}$ was considered the control treatment (Hoagland and Arnon (1950). Constant aeration was maintained in all pots.

The experimental design was completely randomized, with four replications. The $\mathrm{Mn}$ was provided in the form of $\mathrm{MnCl}_{2}$. The complete nutrient solution presented the following composition: $12.0 \mathrm{mmol} \mathrm{L}^{-1}$ of $\mathrm{N}^{-\mathrm{NO}_{3}^{-}}, 4.0 \mathrm{~N}-\mathrm{NH}_{4}^{+} \mathrm{mmol} \mathrm{L}^{-1}, 2.0 \mathrm{mmol} \mathrm{L}^{-1}$ of $\mathrm{P}$,
$6.0 \mathrm{mmol} \mathrm{L}^{-1}$ of $\mathrm{K}, 4.0 \mathrm{mmol} \mathrm{L}^{-1}$ of $\mathrm{Ca}, 2.0 \mathrm{mmol} \mathrm{L}^{-1}$ of $\mathrm{Mg}$, $2.0 \mathrm{mmol} \mathrm{L}^{-1}$ of $\mathrm{S}, 25.0 \mu \mathrm{mol} \mathrm{L} \mathrm{L}^{-1}$ of $\mathrm{B}, 0.5 \mu \mathrm{mol} \mathrm{L} \mathrm{L}^{-1}$ of $\mathrm{Cu}$, $54.0 \mu \mathrm{mol} \mathrm{L}{ }^{-1}$ of Fe, $2.0 \mu \mathrm{mol} \mathrm{L}^{-1}$ of $\mathrm{Zn}$ and $0.5 \mu \mathrm{mol} \mathrm{L}^{-1}$ of Mo. The initial pH (approximately $5.0 \pm 0.5$ ) was monitored daily in each experimental unit to ensure the available $\mathrm{Mn}$; this $\mathrm{pH}$ range was fixed throughout the experiment. Estimates of the Mn species were obtained using the Visual Minteq version 3.1 software (Gustafsson, 2011), and in all of the treatments, approximately $90 \%$ of the Mn was available $\left(\mathrm{Mn}^{2+}\right)$ for ready absorption.

Gas exchange, urease activity, and nitrate reductase activity tests and extraction of antioxidative enzymes and proteins were performed $48 \mathrm{~h}$ after plant exposure to Mn between 8:00 and 12:00 a.m., using the first fully developed trifoliate. Antioxidative enzymes and proteins were also extracted from roots. At the end of the experiment, when the symptoms of Mn toxicity had worsened (10 days of exposure to $\mathrm{Mn}$ ), the first fully developed trifoliate was collected for foliar diagnosis (Lavres Junior et al., 2010) and for characterization of the Mn toxicity symptoms (leaf morphology and scanning electron microscopy).

\subsection{Gas exchange parameters}

Evaluations of gas exchange consisted of non-destructive analyses using a portable gas exchange device (Infra Red Gas Analyzer -IRGA, brand ADC BioScientific Ltd, model LC-Pro). The following were determined: $\mathrm{CO}_{2}$ assimilation rate expressed by area $(A-\mu \mathrm{mol}$ $\mathrm{CO}_{2} \mathrm{~m}^{-2} \mathrm{~s}^{-1}$ ), transpiration $\left(E-\mathrm{mmol} \mathrm{H}_{2} \mathrm{O} \mathrm{m} \mathrm{m}^{-2} \mathrm{~s}^{-1}\right.$ ), stomatal conductance $\left(g_{S}-\mathrm{mol} \mathrm{H}_{2} \mathrm{O} \mathrm{m}^{-2} \mathrm{~s}^{-1}\right)$, and internal $\mathrm{CO}_{2}$ concentration in the substomatal chamber $\left(C_{I}-\mu \mathrm{mol} \mathrm{mol}{ }^{-1}\right)$. The initial conditions imposed for measurements were $1000 \mu \mathrm{mol} \mathrm{m}^{-2} \mathrm{~s}^{-1}$ of photosynthetically active radiation (PAR), provided by LED lamps, $380 \mathrm{ppm}$ of $\mathrm{CO}_{2}$, and a chamber temperature of $28^{\circ} \mathrm{C}$, according to the study of Jiang and Xu (2001).

\subsection{Activity of urease (EC 3.5.1.5)}

Urease activity was measured according to the whole tissue method described by Hogan et al. (1983) and with ammonium determination as suggested by McCullough (1967). One hundred $\mathrm{mg}$ of fresh tissue cut in discs was transferred to assay tubes containing $8 \mathrm{~mL}$ of $50 \mathrm{mM}$ phosphate buffer ( $\mathrm{pH} 7.4$ ), $0.2 \mathrm{M}$ urea, and $0.6 \mathrm{M} \mathrm{n}$-propanol for a period of $3 \mathrm{~h}$. After incubation, an aliquot of $0.5 \mathrm{~mL}$ of supernatant was added to $2.5 \mathrm{~mL}$ of Reagent I $(0.1 \mathrm{M}$ phenol and $170 \mu \mathrm{M}$ sodium nitroprusside). Afterwards, $2.5 \mathrm{~mL}$ of Reagent II $\left(0.125 \mathrm{M} \mathrm{NaOH}+0.15 \mathrm{M} \mathrm{Na}_{2} \mathrm{HPO}_{4} \cdot 12 \mathrm{H}_{2} \mathrm{O}+\mathrm{NaOCl}(3 \%\right.$ $\mathrm{Cl}_{2}$ )) was added for the determination of ammonium. This reaction was performed in capped assay tubes under continuous shaking in a water bath at $37{ }^{\circ} \mathrm{C}$ for $35 \mathrm{~min}$. Ammonium was measured in a spectrophotometer at $625 \mathrm{~nm}$, using a $\mathrm{NH}_{4} \mathrm{Cl}$ standard calibration curve, and urease activity was expressed as $\mu \mathrm{mol} \mathrm{N}-\mathrm{NH}_{4}^{+} \mathrm{h}^{-1} \mathrm{~g}^{-1}$ FW (fresh weight).

\subsection{Activity of nitrate reductase (EC 1.7.1.1)}

The in vivo nitrate reductase activity was determined according to Reis et al. (2009) with slightly modifications. Leaf samples were collected at 8:30 a.m., stored in plastic bags, and transported to the laboratory on ice. Afterwards, $200 \mathrm{mg}$ of fresh tissue cut in discs was transferred to assay tubes containing $5 \mathrm{~mL}$ of phosphate buffer solution, pH 7.5 (100 mM potassium phosphate buffer $+100 \mathrm{mM}$ $\mathrm{KNO}_{3}$ ). Thereafter, the assay tubes (wrapped in aluminum foil to protect from the light) were incubated in a $30{ }^{\circ} \mathrm{C}$ water bath for $60 \mathrm{~min}$. The reaction was performed with $100 \mu \mathrm{L}$ of supernatant $+1.9 \mathrm{~mL}$ of distilled water $+0.5 \mathrm{~mL}$ of $1 \%$ sulfanilamide in $2 \mathrm{M} \mathrm{HCl}$, followed by $0.5 \mathrm{~mL}$ of $0.02 \%$ naphtylenediamine 
solution. The nitrite $\left(\mathrm{NO}_{2}^{-}\right)$produced was measured in a spectrophotometer at $540 \mathrm{~nm}$, using a nitrite standard calibration curve. The enzyme activity was directly related to the amount of $\mathrm{NO}_{2}^{-}$, and the results were expressed in $\mu \mathrm{mol} \mathrm{NO} \mathrm{N}_{2}^{-1} \mathrm{~g}^{-1} \mathrm{FW}$.

\subsection{Extraction of antioxidative enzymes and proteins}

The plant material was macerated in a mortar containing liquid nitrogen. The protein extracts were obtained from $1.5 \mathrm{~g}$ of fresh plant material, together with the addition of PVPP (polyvinylpolypyrrolidone) corresponding to $20 \%$ (w:v). Protein extraction proceeded using a potassium phosphate buffer solution at $100 \mathrm{mmol} \mathrm{L}^{-1}$ (pH 7.5), EDTA (ethylenediaminetetraacetic acid) at $1 \mathrm{mmol} \mathrm{L}^{-1}$, and DDT (dithiothreitol) at $1 \mathrm{mmol} \mathrm{L}^{-1}$. The homogenized extracts were centrifuged at $10.000 \mathrm{rpm}$ for $30 \mathrm{~min}$ at $4{ }^{\circ} \mathrm{C}$. The supernatant was stored in Eppendorf tubes, frozen in liquid nitrogen, and stored in a freezer at $-80{ }^{\circ} \mathrm{C}$. The soluble protein concentration was determined by the method of Bradford (1976) using BSA (bovine serum albumin) as a standard. Aliquots of $100 \mu \mathrm{L}$ of the extract were mixed in $5 \mathrm{~mL}$ of Bradford reagent with four replications. Reading was performed in a spectrophotometer at $595 \mathrm{~nm}$. The results were used to calculate the antioxidative enzyme concentration.

\subsection{Activity of peroxidase (POD, EC. 1.11.1.7)}

The method of Allain et al. (1974) was used to determine the POD activity present in the leaf tissues of soybean. From the tissue extract obtained by the enzymatic extraction process described above, an aliquot of $0.5 \mathrm{~mL}$ was removed and added to $0.5 \mathrm{~mL}$ of potassium phosphate buffer $0.2 \mathrm{M}(\mathrm{pH} 6.7), 0.5 \mathrm{~mL}$ of $\mathrm{H}_{2} \mathrm{O}_{2}$ (hydrogen peroxide), and $0.5 \mathrm{~mL}$ of aminoantipyrine. The tubes were placed in a water bath at $30^{\circ} \mathrm{C}$ for $5 \mathrm{~min}$. After incubation (5 min), $2 \mathrm{~mL}$ of ethanol was added to stop the reaction, and after being cooled at room temperature, the samples were vortexed and read in a spectrophotometer $(\lambda=505 \mathrm{~nm})$. In the control, the enzyme extract was substituted by $0.2 \mathrm{M}$ potassium phosphate buffer ( $\mathrm{pH}$ 6.7). The total enzyme activity was expressed in $\mu \mathrm{mol}$ de $\mathrm{H}_{2} \mathrm{O}_{2} \mathrm{~min}^{-1} \mathrm{mg}$ of protein ${ }^{-1}$.

\subsection{Activity of the superoxide dismutase (SOD, EC 1.15.1.1)}

The SOD activity was determined according to Giannopolitis and Ries (1977). The reaction was conducted in a reaction chamber (box) under the illumination of a $15 \mathrm{~W}$ fluorescent lightbulb at $25{ }^{\circ} \mathrm{C}$. An aliquot $(50 \mu \mathrm{L})$ of the sample was added to a mixture of $5 \mathrm{~mL}$ that contained sodium phosphate buffer ( $50 \mathrm{mmoL} / \mathrm{L}), \mathrm{pH} 7.8$, methionine $(13 \mathrm{mmoL} / \mathrm{L})$, NBT $(75 \mathrm{mmoL} / \mathrm{L})$, EDTA $(0.1 \mathrm{mmoL} / \mathrm{L})$, and riboflavin $(2 \mu \mathrm{moL} / \mathrm{L})$. The tubes were placed inside the box, closed to any external light, and maintained under the box lighting for $15 \mathrm{~min}$ for the formation of the blue formazan compound produced by the photoreaction of NBT. Other test tubes with the same mixture were covered with aluminum foil to prevent light exposure; these test tubes served as the control for each sample. After $15 \mathrm{~min}$, the material was homogenized by vortexing. Readings were taken in a spectrophotometer at $560 \mathrm{~nm}$, and the results were expressed in U SOD mg protein ${ }^{-1}$.

\subsection{Catalase activity (CAT, 1.11.1.6)}

CAT activity was determined by monitoring the degradation of $\mathrm{H}_{2} \mathrm{O}_{2}$ at $240 \mathrm{~nm}$ according to the methodology of Azevedo et al. (1998). In the test tubes, $1 \mathrm{~mL}$ of potassium phosphate buffer $100 \mathrm{mM}$, pH 7.5, and $2 \mu \mathrm{L} \mathrm{H}_{2} \mathrm{O}_{2} 30 \%$ was added, followed by $150 \mu \mathrm{L}$ of protein extract. Immediately after the addition of the protein extract, the tubes were quickly mixed by vortexing. Enzyme activity was determined by the decomposition of $\mathrm{H}_{2} \mathrm{O}_{2}$ during a 2 min interval in a spectrophotometer at the wavelength of $240 \mathrm{~nm}$ at $25^{\circ} \mathrm{C}$. The results were expressed in $\mu \mathrm{moL} \mathrm{min}^{-1} \mathrm{mg}$ protein ${ }^{-1}$.

\subsection{Dry mass production of the plants}

At harvest (at phonological stage V4, Fehr et al., 1971), the plants were separated into shoots (leaves + stem) and roots. The material was identified, packaged in paper bags, and dried in an oven at \pm $65{ }^{\circ} \mathrm{C}$ for 2 days, with the subsequent measurement of dry mass.

\subsection{Chemical analysis of the plant tissue}

The concentration of phosphorus $(\mathrm{P})$, potassium (K), calcium $(\mathrm{Ca})$, magnesium $(\mathrm{Mg})$, sulfur $(\mathrm{S})$, boron $(\mathrm{B})$, cupper $(\mathrm{Cu})$, iron $(\mathrm{Fe})$, $\mathrm{Mn}$ and zinc $(\mathrm{Zn})$ were determined in the shoot and root. Nitricperchloric digestion was performed (Miller, 1998), and the identity and amount of nutrients were determined using radial visualization of the inductively coupled plasma optical emission spectrometry (ICP-OES), equipped with a nebulization chamber. The following emission line was used: $\mathrm{P}_{\mathrm{I}} 213.618 \mathrm{~nm}$; $\mathrm{K}_{\mathrm{I}}$ $769.897 \mathrm{~nm}$; Ca I $422.673 \mathrm{~nm} ; \mathrm{Mg}_{\text {I }} 280.270 \mathrm{~nm} ; \mathrm{S}_{\text {I }} 181.972 \mathrm{~nm}$; B I

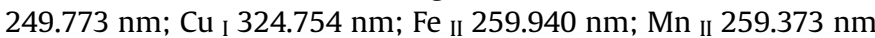
and $\mathrm{Zn}_{\text {II }} 231.865 \mathrm{~nm}$.

\subsection{Leaf and root morphology}

After 7 days of exposure to Mn (at V1 phonological stage, Fehr et al., 1971), the plants were collected for symptomatology and histological section analysis. Fragments of leaves and roots were collected and fixed in F.A.A. 70 solution (37\% formaldehyde, acetic acid, and $70 \%$ ethanol at a ratio of 1.0:1.0:18.0-V/V) and stored until the date of the analysis according to the methodology described by Lavres Junior et al. (2010).

All of the plant tissue fragments received the relevant procedures for dehydration, diafanization, inclusion, and fixation. With the aid of a Leica microtome table containing a steel blade, cross sections of 8-14 $\mu \mathrm{m}$ were made from each embedded fragment. For the histological slides, the first cross-sections that showed the best preserved material were selected, i.e., without damage or injury caused by cutting the plant tissue. All of the chosen sections were fixed with Mayer adhesive, stained with safranin $1 \%$ and mounted on slides and cover slips with Entellan adhesive. All of the slides were observed under an Olympus optical microscope with a coupled camera for measuring the anatomical parameters by means of the CellSens Standard image analysis program, calibrated with a microscopic rule in the same zoom level of the photographs.

In the midrib region of the leaves in the cross-sections, the following morphoanatomic characteristics were observed: epidermal thickness of the lower or abaxial face (ABET); epidermal thickness of the upper or adaxial face (ADET); leaf phloem diameter (LPD); and leaf xylem diameter (LXD). The morphoanatomic root characteristics were: root epidermis thickness (RET); root phloem diameter (RPD); and root xylem diameter (RXD) (Carlquist, 1975). For each characteristic, 10 measurements were performed per slide. The plots were represented by the mean values obtained for each characteristic.

\subsection{Scanning electron microscopy}

The leaf and root plant material was fixed in modified Karnovsky fixative (2.5\% glutaraldehyde, $2.5 \%$ formaldehyde in sodium cacodylate buffer $0.05 \mathrm{M}, \mathrm{pH} 7.2$ ), post-fixed with osmium tetroxide $\left(\mathrm{OsO}_{4}\right)$, and dehydrated in increasing solutions of acetone $(30,50$, 
70,90 , and 100\%). Subsequently, the specimens were dried to their critical point with liquid $\mathrm{CO}_{2}$ (Balzers $\mathrm{CPD} 030$ ), coated with sputterer (MED 010 Balzers) for surface coating with a thin layer of gold, and examined in a scanning electron microscope (EVO-LS15-ZEIS).

\subsection{Analysis of the results}

In all of the datasets considered, the normality of the data was analyzed using the Anderson-Darling test, and homoscedasticity was analyzed with the variance equation test (or Levenn's test). The results were subjected to statistical analysis using SAS statistical software - System for Windows 9.2. The means were compared using the Tukey test $(\mathrm{p}<0.05)$.

\section{Results}

\subsection{Dry mass production}

The effect of Mn toxicity in soybean plants was observed for the shoots with no effect on dry root mass accumulation (Fig. 1). Thus, plants cultivated in the control treatment $\left(2 \mu \mathrm{mol} \mathrm{L}{ }^{-1}\right)$ presented the highest production of dry mass. Plants cultivated with the dose of $0 \mu \mathrm{mol} \mathrm{L} \mathrm{L}^{-1}$ also showed reduced growth, presenting results similar to plants cultivated with $10 \mu \mathrm{mol} \mathrm{L}^{-1}$. The increase in $\mathrm{Mn}$ available to plants reduced the dry mass accumulation of the soybean shoots, with a reduction of $21 \%$ in the dry mass of the plants cultivated in the highest concentration of $\mathrm{Mn}\left(300 \mu \mathrm{mol} \mathrm{L} \mathrm{L}^{-1}\right)$ compared to the average of the cultivated plants in the control treatment. Thus, the soybean plant growth was compromised by

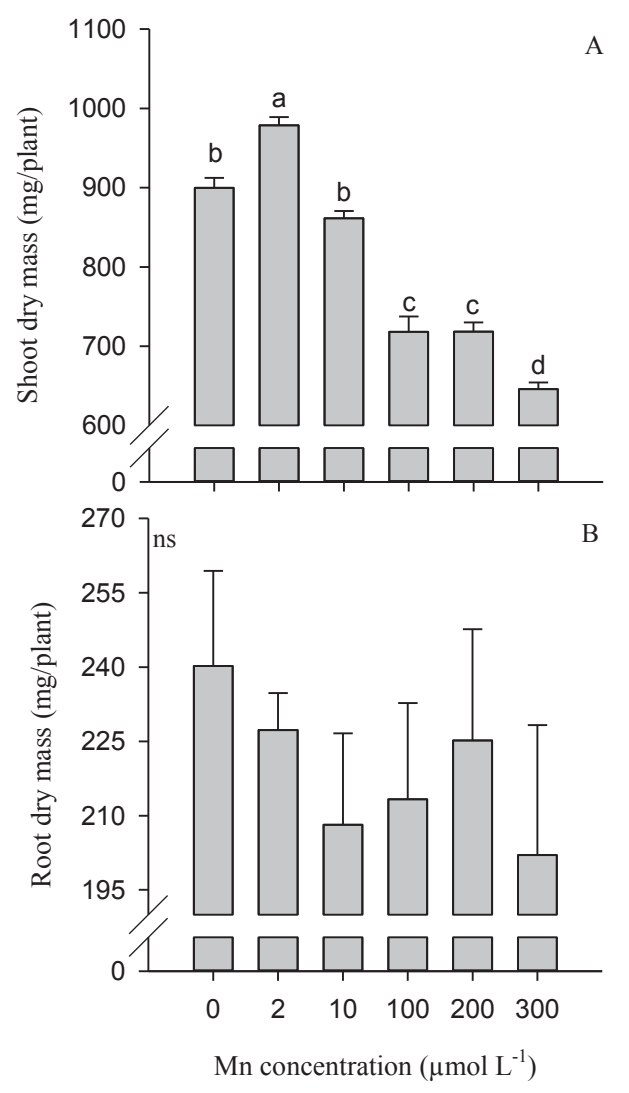

Fig. 1. Soybean shoot (A) and root (B) dry mass as a function of Mn concentrations in nutrient solution. The letters correspond to a significant difference at $5 \%$ probability level ( $\mathrm{p} \leq 0.05$ ). ns: not significant. Error bars indicate the standard error of the mean $(\mathrm{n}=4)$. the increase in $\mathrm{Mn}$ doses in the culture solution, resulting in reduced dry mass production.

\subsection{Gas exchange and nitrogen assimilating enzymes}

Plants cultivated in the control treatment presented the highest $\mathrm{CO}_{2}$ assimilation rate $(A)$ and stomatal conductance $\left(g_{S}\right)$ (Fig. $2 \mathrm{~A}$ and D). The cultivated plants reduced the $A$ and $g_{S}$ in function of the increase in available $\mathrm{Mn}$, and the plants grown under control of $\mathrm{Mn}$ $\left(2 \mu \mathrm{mol} \mathrm{L}{ }^{-1}\right)$ showed $A$ and $g_{S}$ values that were 47 and $23 \%$ greater than the plants cultivated in the highest Mn dose, respectively. Moreover, Mn deficiency also promoted a reduction in $A$ and $g_{S}$. A different result was observed for the transpiration rate $(E)$ and internal $\mathrm{CO}_{2}$ concentration $\left(C_{i}\right)$, in which the increased Mn concentrations resulted in higher results (Fig. $2 \mathrm{C}$ and D). The highest $\mathrm{Mn}$ concentration increased $E$ and $C_{i}$ by 6 and 17\%, respectively. Thus, a reduced assimilation capacity (low $A$ and $g_{S}$ ) and lower carbon usability $\left(C_{i}\right)$ was observed, as well as the deregulation of $E$.

The lowest activity of nitrate reductase was found in the plants grown with the highest dose of Mn (Fig. 3A); the plants cultivated in the control treatment and the Mn deficient plants showed the highest activity of this enzyme. The plants cultivated in the highest Mn dose showed a $39 \%$ reduction in enzyme activity compared to the plants cultivated in the control treatment (Fig. 3A). Thus, similar to photosynthetic rate (Fig. 2), the toxicity of Mn compromised nitrate assimilation in soybean leaves. The lowest urease activity was detected in the plants deficient in $\mathrm{Mn}$ and in the plants grown at the highest dose of Mn (Fig. 3B). Thus, both the omission of Mn and the greater availability of $\mathrm{Mn}$ in the nutrient solution compromised urea metabolism in soybean plants. However, the plants cultivated with doses of $10 \mu \mathrm{mol} \mathrm{L}^{-1}$ presented higher activity of this enzyme than the plants cultivated with the control Mn dose.

\subsection{Antioxidant enzymes}

Enzyme activity of the antioxidant systems evaluated - POD, SOD, and CAT - were higher in the plants cultivated with higher Mn doses, both in the roots and in the leaves (Fig. 4A-F). The activity of these enzymes in the root was approximately 10 times greater than in the leaves, except for CAT. This result indicates the greater effects of POD and SOD in the roots for Mn toxicity responses in soybean plants. CAT presented the highest protective effect against the formation of ROS (reactive oxygen species) in soybean leaves. The plants deficient in Mn that were cultivated in the control nutrient solution showed similar activity of these enzymes, indicating no effect of Mn deficiency on the production of ROS.

\subsection{Leaf and root morphology}

The observations made by optical microscopy allowed the identification of modifications in the leaf and root structures due to increased Mn availability in the nutrient solution (Figs. 5 and 6). The plants deficient in Mn did not differ from those grown in the control nutrient solution (Figs. 5-7). The Mn doses reduced the adaxial epidermis thickness (ADET), making it thinner (Fig. 6B). However, there were no effects of the Mn doses on the abaxial epidermal thickness (ABET), the LPD, or the LXD (Fig. 6). Thus, Mn toxicity in soybean plants mainly modified the ultrastructure of the root anatomy and epidermis on the upper surface of the leaf. The leaf diagnosis used for the biochemical and physiological analyses, as well as the analysis of the deficiency symptoms and Mn toxicity, leaf morphology, and scanning electron microscopy, are shown in Fig. 7. The major visual differences were found in the leaves of 

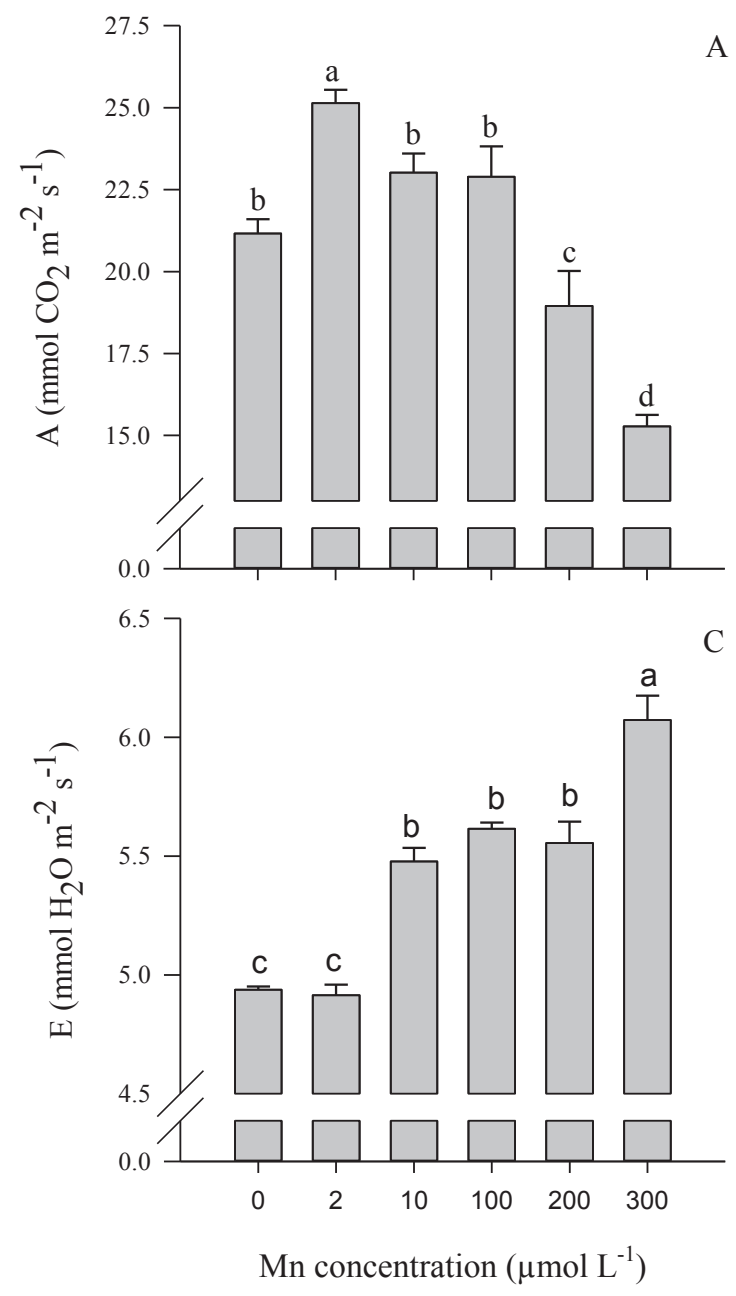
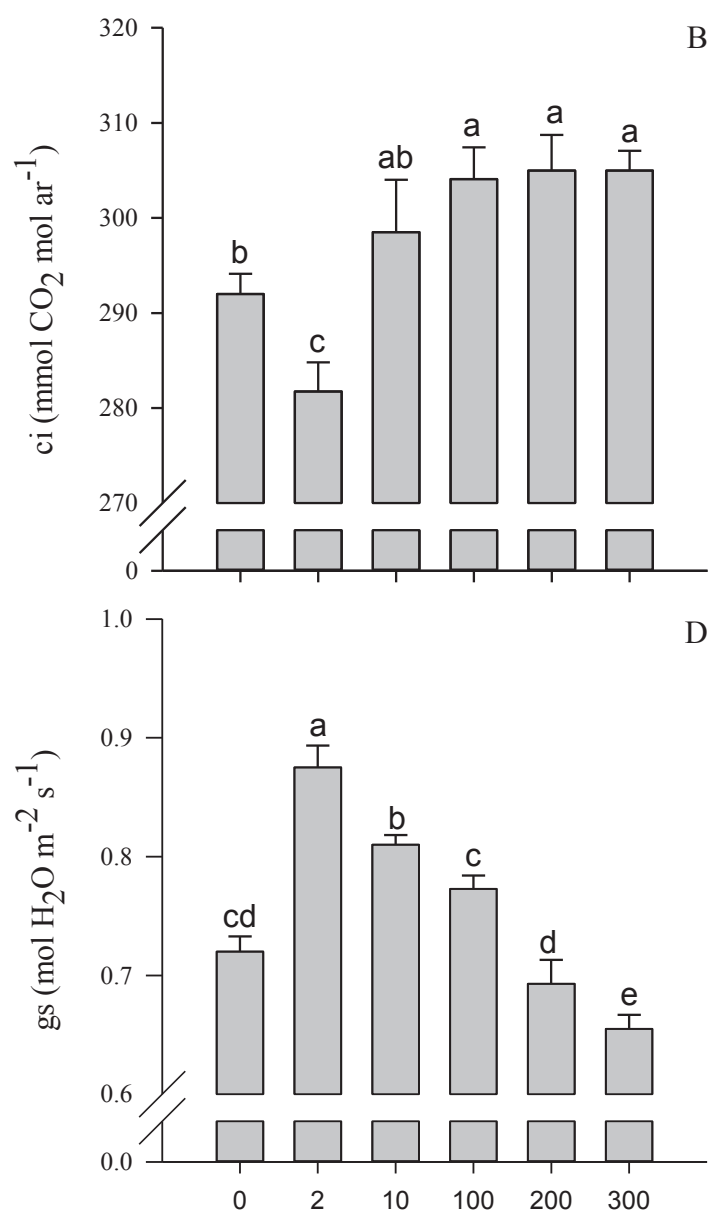

Mn concentration $\left(\mu \mathrm{mol} \mathrm{L}{ }^{-1}\right)$

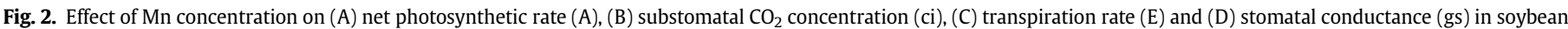
leaves in nutrient solution. Error bars indicate the standard error of the mean $(n=4)$.

plants grown with higher Mn doses (200 and $300 \mu \mathrm{mol} \mathrm{L}^{-1}$ ) (Fig. 7E and $F$ ). These leaves showed visual symptoms of toxicity, in which this symptom is indicated by distortion of the leaf blade and the appearance of chlorotic spots on the edges of the leaves (Fig. 7E), with subsequent necrosis (Fig. 7F) and purple spots (Fig. 8).

\subsection{Symptomatology of Mn toxicity in soybean leaves}

Via the EDS technique, the distribution of the nutrients $\mathrm{K}, \mathrm{Ca}$, $\mathrm{Mn}, \mathrm{Mg}$, and $\mathrm{P}$ was characterized in the necrotic area caused by $\mathrm{Mn}$ toxicity in soybean leaves (Fig. 8). The other essential elements with potential characterization by scanning electron microscopy showed no change in the distribution pattern. Compared to the lesioned area, $\mathrm{Mg}, \mathrm{P}$, and $\mathrm{K}$ showed superior intensity outside of necrosis (Fig. 9B-D), corresponding to 65,45 , and $80 \%$ of the intensity, respectively. The greatest intensity outside the lesioned area was observed for $\mathrm{K}$, characterizing an antagonistic distribution effect with $\mathrm{Mn}$ and Ca between the healthy and lesioned area. Mn and Ca presented three intensity ratios in the necrotic lesion (Fig. 9E and F). A greater intensity of Mn and Ca was observed between necrosis and the uninjured leaf tissue (Fig. 9A and E). For Ca, the highest intensity was observed in the necrotic tissue (Fig. 9A and F).

The ultrastructural characteristics of the root and leaf in relation to Mn doses in the nutrient solution are observed in Fig. 10 (A-F) and Fig. $11(\mathrm{~A}-\mathrm{F})$, respectively. The images reveal disorganization and small changes in the adaxial epidermis. The disorganization and cellular disarray on the adaxial part of the soybean leaves cultivated in a nutrient solution with a high concentration of $\mathrm{Mn}$ occurred because of the reduced ADET, becoming thinner as observed in Fig. 6B. There was no reduction in the stomata number in relation to the control treatment $\left(2 \mu \mathrm{mol} \mathrm{L}^{-1}\right)$. At the highest $\mathrm{Mn}$ dose $\left(300 \mu \mathrm{mol} \mathrm{L}^{-1}\right)$, there were changes in the epidermis and tissue agglomeration, resulting in epidermal hypertrophying, i.e., a large disruption in the cellular arrangement (Fig. 10F). With regards to the roots, no external cell disorganization was observed (Fig. 11A-F).

\subsection{Concentration of macro and micronutrients}

The concentrations of $\mathrm{P}$ in the shoot and $\mathrm{K}$ in the shoot and root were influenced by Mn doses (Fig. 12A and B). The Ca concentration in the root tissue decreased with the increase of $\mathrm{Mn}$ in the cultivation solution (Fig. 12C). A similar result was observed for $\mathrm{Mg}$ concentrations in shoots (Fig. 12D) and for S concentrations in roots (Fig. 12E), which were reduced as a function of the increase in Mn concentration. The highest $\mathrm{B}$ concentration in the shoot was detected in plants cultivated with $200 \mu \mathrm{mol} \mathrm{L}^{-1} \mathrm{Mn}$. However, the highest $\mathrm{B}$ concentration in the roots was found in plants cultivated with dose of $100 \mu \mathrm{mol} \mathrm{L}^{-1}$ (Fig. 12F).

Regarding cationic micronutrients, the Mn concentration 

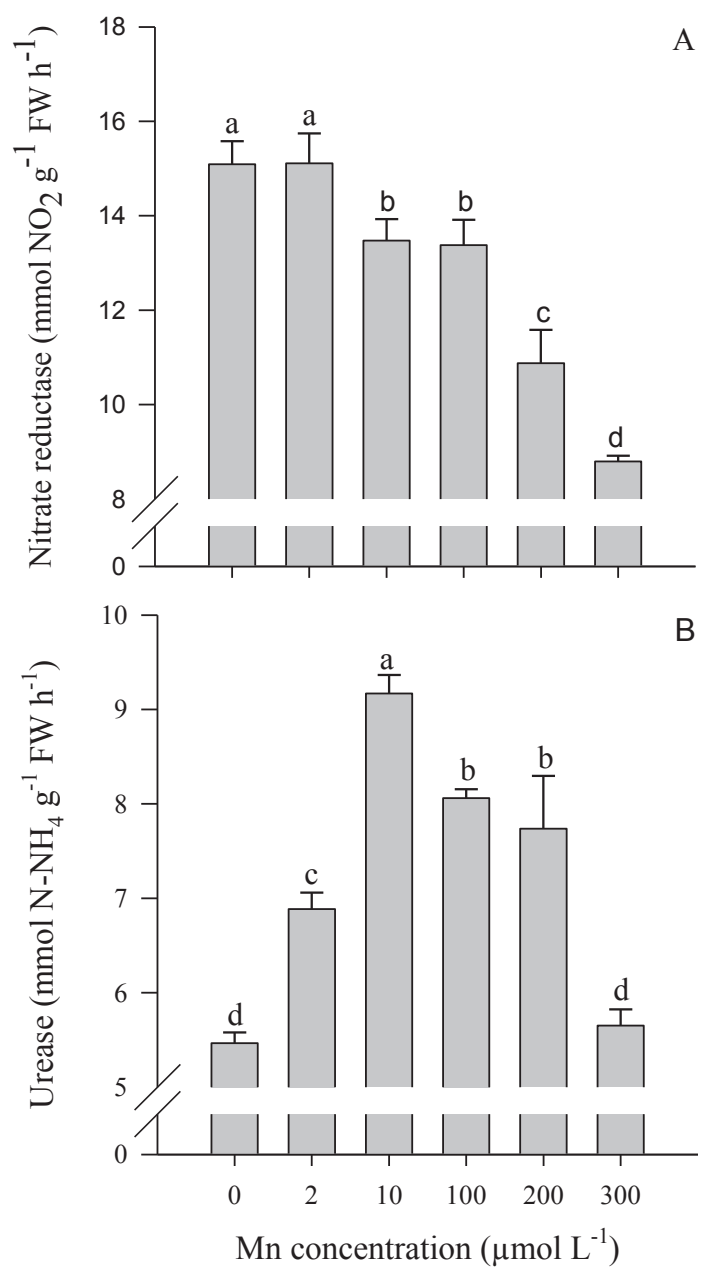

Fig. 3. Effect of Mn concentration on nitrate reductase (A) and urease (B) activity in soybean leaves in nutrient solution. Error bars indicate the standard error of the mean $(n=4)$.

influenced the concentrations of $\mathrm{Cu}, \mathrm{Fe}, \mathrm{Mn}$ and $\mathrm{Zn}$ in the roots (Fig. 13). Concentrations of $\mathrm{Mn}$ in the shoots and roots were influenced by the Mn dose (Fig. 13C). Moreover, the plants cultivated with doses of $300 \mu \mathrm{mol} \mathrm{L}^{-1}$ presented highest concentrations of Mn in the shoots and roots.

\section{Discussion}

\subsection{Dry mass production, gas exchange, and nitrogen assimilating enzymes}

The dry mass productivity of the soybean plants decreased with the increase in Mn dose (Fig. 1); moreover, plants cultivated under higher Mn doses presented high Mn concentrations in shoots and roots (Fig. 13C) and symptoms of toxicity (Fig. 7E and F) in the leaves, similar to that observed in soybean (Lavres Junior et al., 2010), Vigna unguiculata (Wissemeier et al., 1992) and rice (Lidon, 2002). Thus, the higher concentrations of Mn caused toxicity effects in the present work. The lower dry mass reduction is an excellent indicator of species or genotypes tolerant to Mn toxicity (Fernando and Lynch, 2015). In sugarcane, Mn toxicity decreased the dry mass production according to genotype analyzed (Zambrosi et al., 2016). The reduction in dry mass accumulation by Mn toxicity was related in soybean shoots (Lavres Junior et al., 2010; Millaleo et al., 2013; Shuai, 2016) and roots (Chen et al., 2016).
Reduced shoot growth was the result of the toxic accumulation of Mn in the plant tissue (Fig. 13C), which in turn compromised the carbon and nitrogen metabolism of the soybean plants (Figs. 2 and 3 ). The reduction of $\mathrm{CO}_{2}$ assimilation (Fig. $2 \mathrm{~A}$ ) in plants cultivated under high $\mathrm{Mn}$ concentrations suggests the negative effect of this metal in toxic concentrations on the carbon fixation process. This effect occurs because plants cultivated in toxic Mn concentrations also showed a higher internal carbon concentration in the substomatal chamber (Fig. 2B), indicating low carboxylation efficiency of the plants. The lower Calvin cycle efficiency in plants with stress occurred because of the reduced availability of $\mathrm{NADP}^{+}$for the carbon fixation process and the reduced stability of photosystem II (Gururani et al., 2015). In Arabidopsis thaliana, degradation of photosystem I was reported by Mn toxicity (Millaleo et al., 2013). In the present study, Mn toxicity indicated a similar effect on the photosynthesis process in soybean plants.

The lower growth of plants grown in toxic concentrations of Mn is also explained by lower transpiration. This was the result of physiologically uncontrolled water use caused by oxidative damage resulting from $\mathrm{Mn}$ toxicity. This result was evidenced by the results of a low $g_{S}$ (Fig. 2B) and a high $E$ (Fig. 2D) of plants cultivated in higher concentrations of $\mathrm{Mn}$, i.e., even with low stomata open indices, the plants maintained high transpiration rates. However, under severe conditions of Mn toxicity, there was a high disorganization of the plant tissue, characterizing low stomatal opening. Lidon (2002) observed that stomatal opening and the length of the stomata decreased significantly in rice plants cultivated in nutrient

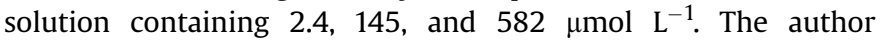
concluded that the reduction of stomatal conductance is associated with the physiological control of rice plants as a mechanism responsible for low $\mathrm{Mn}$ transport from the roots to shoots. In the present study, although the stomatal opening was small, the transpiration was greater; these factors are responsible for the high translocation of $\mathrm{Mn}$ from the roots to shoots, in which the leaf concentration ranged from 12 to $501 \mathrm{mg} \mathrm{kg}^{-1}$ (Fig. 13C).

The high translocation of $\mathrm{Mn}$ to the shoot and accumulation in the shoot can result in damage to the photosynthetic apparatus. The production of ROS by the plants as a function of the Mn toxicity degrades the photosynthetic apparatus, which in turn reduces the photosynthetic capacity (Weng et al., 2013; Rojas-Lillo et al., 2014). In the present study, degradation of the photosynthetic apparatus directly influenced the efficiency of carboxylation and water use by soybean plants.

Metal toxicity causes negative effects of ROS accumulation in chloroplasts and inhibits renewal of the D1 protein, which is required for the repair of photosystem II (Nishiyama et al., 2011); moreover, the suppression of ROS degrades chloroplast enzymes (Kato and Sakamoto, 2014) and promotes breakdown of the thylakoid architecture (Gratão et al., 2009). Some studies with Mn (Weng et al., 2013; Rojas-Lillo et al., 2014) have demonstrated that the toxicity of this metal reduces the photosynthesis rate by degradation of the photosynthetic apparatus.

\subsection{Antioxidative enzymes}

The negative effect of Mn toxicity on the photosynthetic process in the present study was a function of oxidative stress. Increased activity of enzymes of the antioxidant system - SOD, CAT, and POD - indicated excessive production of $\mathrm{H}_{2} \mathrm{O}_{2}$ and ROS in plants cultivated under stress - Mn toxicity. The plants deficient in Mn $\left(0 \mu \mathrm{mol} \mathrm{L}{ }^{-1}\right)$ showed antioxidant enzyme activity similar to plants cultivated in the control treatment $\left(2 \mu \mathrm{mol} \mathrm{L}^{-1}\right)$, both in the leaves and in the roots (Fig. 4). Thus, oxidative stress was affected by the Mn toxicity conditions and not by deficiency of this nutrient. Activity of the antioxidant enzymes was more accentuated in soybean 

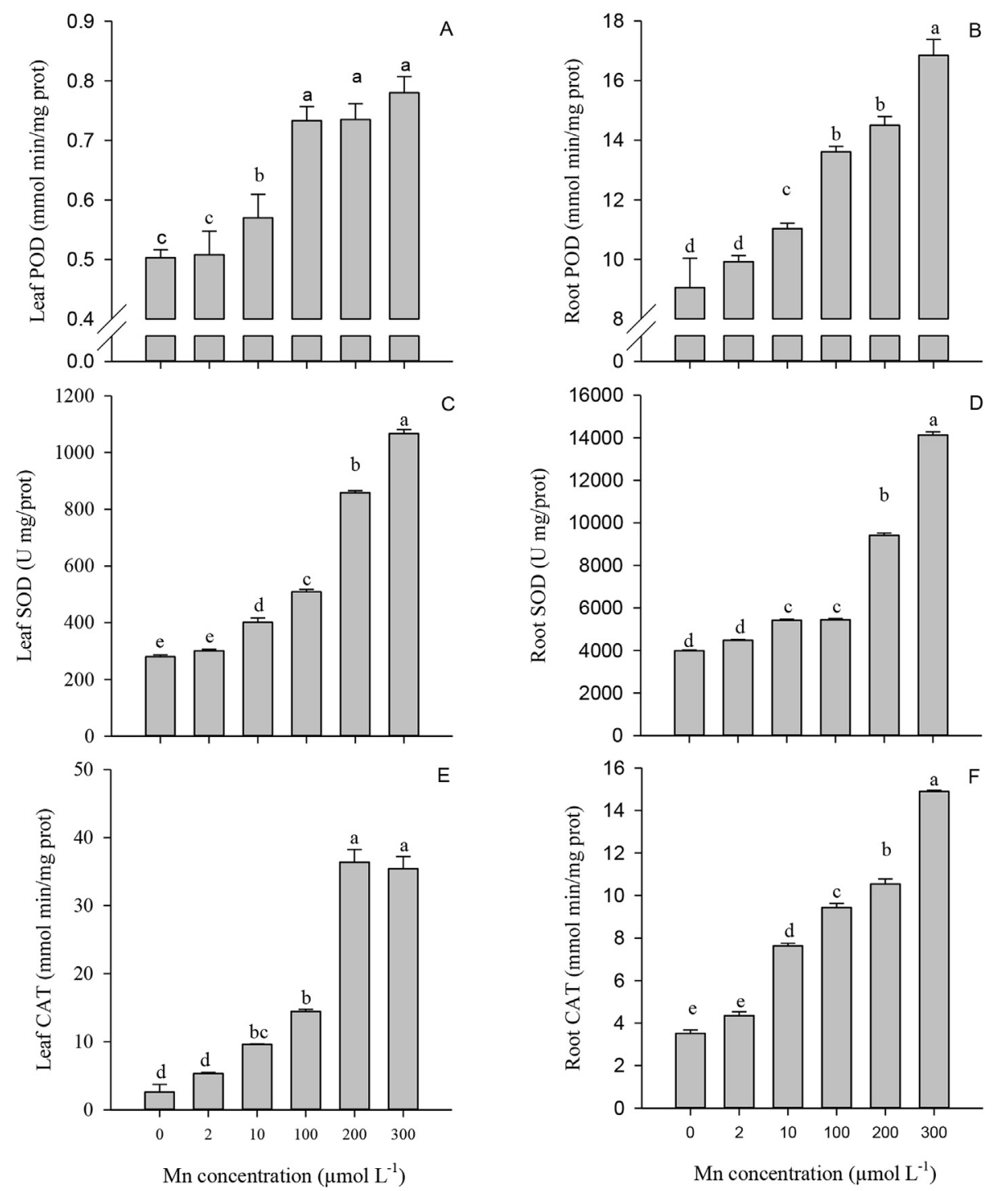

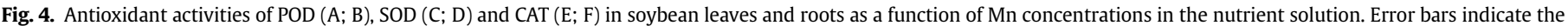
standard error of the mean $(n=4)$.

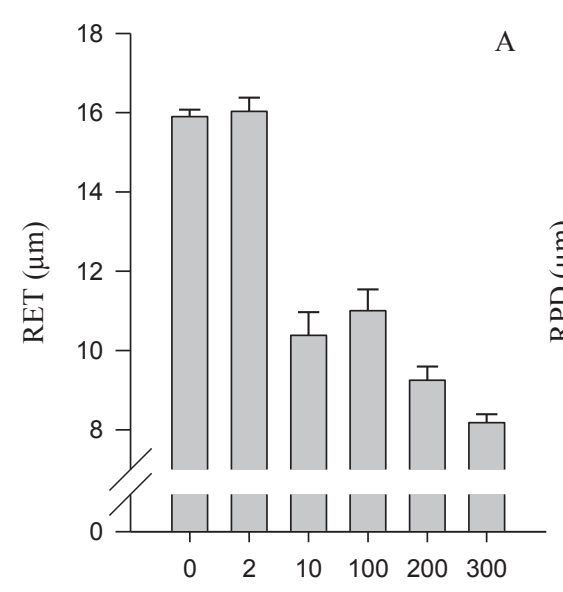

Mn concentration $\left(\mu \mathrm{mol} \mathrm{L}^{-1}\right)$

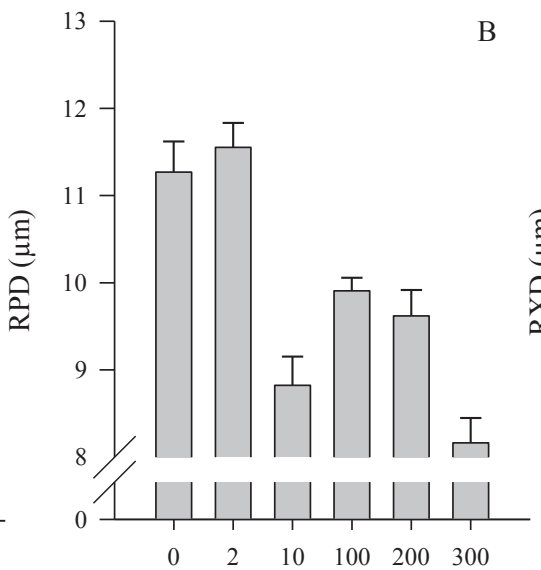

Mn concentration $\left(\mu \mathrm{mol} \mathrm{L}{ }^{-1}\right)$

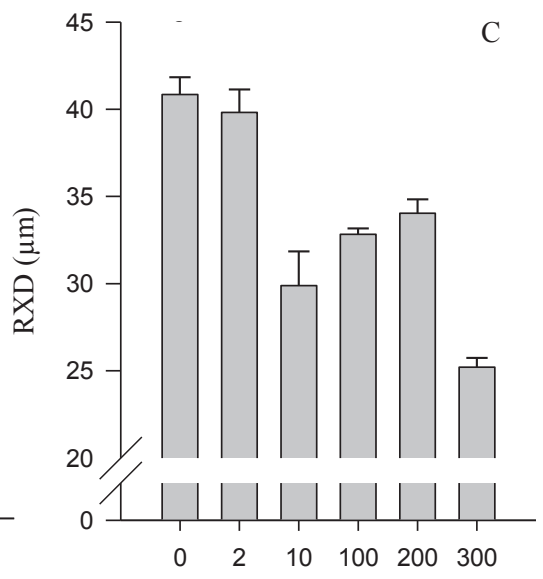

Mn concentration $\left(\mu \mathrm{mol} \mathrm{L}{ }^{-1}\right)$

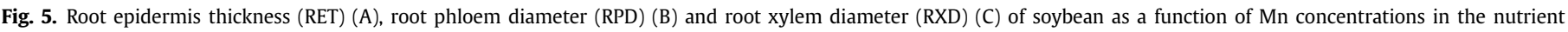
solution. Error bars indicate the standard error of the mean $(n=4)$. 

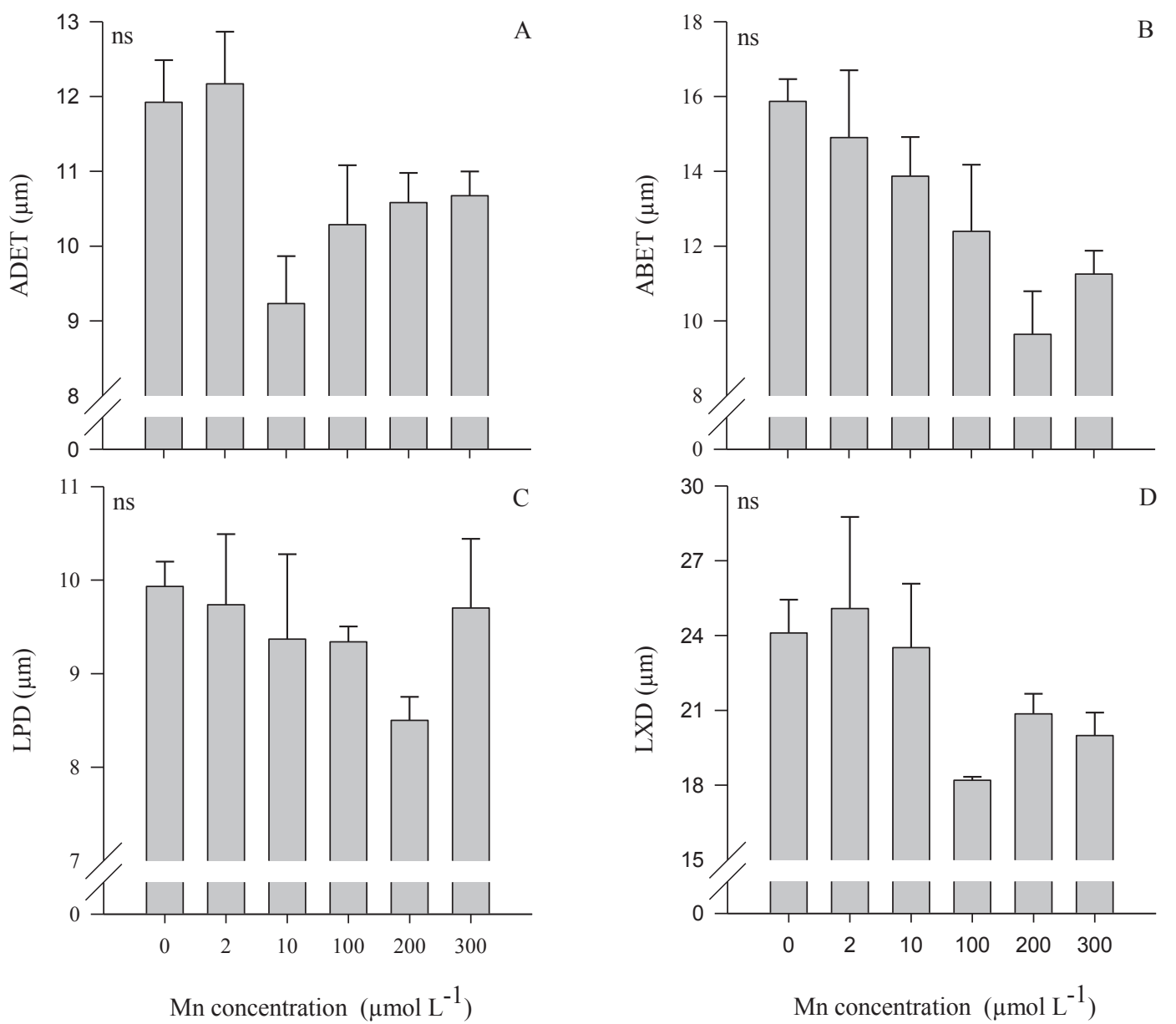

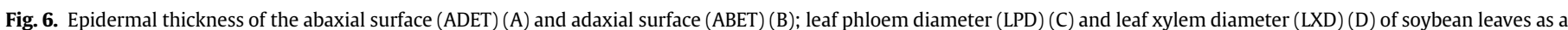
function of Mn concentrations in nutrient solution. Error bars indicate the standard error of the mean $(n=4)$. ns: not significant.

plants at doses of $10 \mu \mathrm{mol} \mathrm{L}{ }^{-1}$ and higher (Fig. 4). However, visual symptoms of aggravated toxicity were observed only in plants cultivated in a dose 150 times greater than recommended $\left(300 \mu \mathrm{mol} \mathrm{L}^{-1}\right)$.

The soybean plants showed distinct activity patterns for the enzymes tested according to the tissue analyzed. The activity of CAT was greater in the leaves than the roots (Fig. 4E and F). CAT represents the major constituent of the matrix of peroxisomes (Reis et al., 2015). However, POD activity was contrary to that observed for the other peroxidase analyzed - CAT - exhibiting lower activity in leaves and higher values in the roots. POD acts directly on the reduction of $\mathrm{H}_{2} \mathrm{O}_{2}$ to prevent oxidative damage, protecting cellular constituents (Merlin et al., 2012). The increased activity of POD in the root - the first tissue in contact with the toxic element - is mainly explained by the participation of this enzyme in the biosynthesis of lignin, which can prevent absorption of the toxic element via the construction of a physical barrier (Gratão et al., 2005), in addition to its antioxidant function. The increased CAT activity in leaves is a result of its metabolic function of oxidizing toxins using $\mathrm{H}_{2} \mathrm{O}_{2}$ (Noctor et al., 2002). These toxins (e.g., phenols, formic acid, and formaldehyde) have naturally higher concentrations in the plant shoots. Aibibu et al. (2010) found the same pattern of CAT and POD when studying the toxic effects of cadmium (Cd) in vetiver grass (Vetiveria zizanioides), which is tolerant to metal stress.

The results observed for SOD indicate the same activity pattern as POD - high in the roots and low in the leaves. This enzyme catalyzes the removal of the superoxide radical by dismutation (Gratão et al., 2009). High SOD activity in the root is explained by its dominant role in the antioxidant system of several species; therefore, its activity tends to be higher in the tissue in contact with the source of toxicity (Gratão et al., 2005). Thus, POD and SOD had an important role in protection against ROS in the root, whereas CAT was more important in the leaves. This information is essential to the understanding that different antioxidant enzymes showed different contributions to the oxidative state of the cell.

\subsection{Symptomatology of Mn toxicity and ultrastructural alterations of leaves and roots}

The Mn doses significantly reduced the RET, RPD, and RXD of the soybean, as shown in Fig. 5. However, no alteration or external cell derangement of the roots was observed via scanning electron microscopy, which may be an indicator of greater Mn partitioning in the root apoplast and the action of PODs in this compartment (Führs et al., 2009; Lavres Junior et al., 2010). This mechanism can be understood as a synchronous result of strategies, the first of which is based on the apoplastic exclusion of Mn toxic to the root apex by the release of ligands/chelating agents such as organic acids - citrate, malate, and oxalate, and phenolic compounds. The second strategy is the internal/symplastic detoxification by ligands/ chelating agents such as organic acids (citrate, malate, and oxalate), phytochelatins, and compartmentalization of the Mn-complex in vacuoles (Millaleo et al., 2010). 

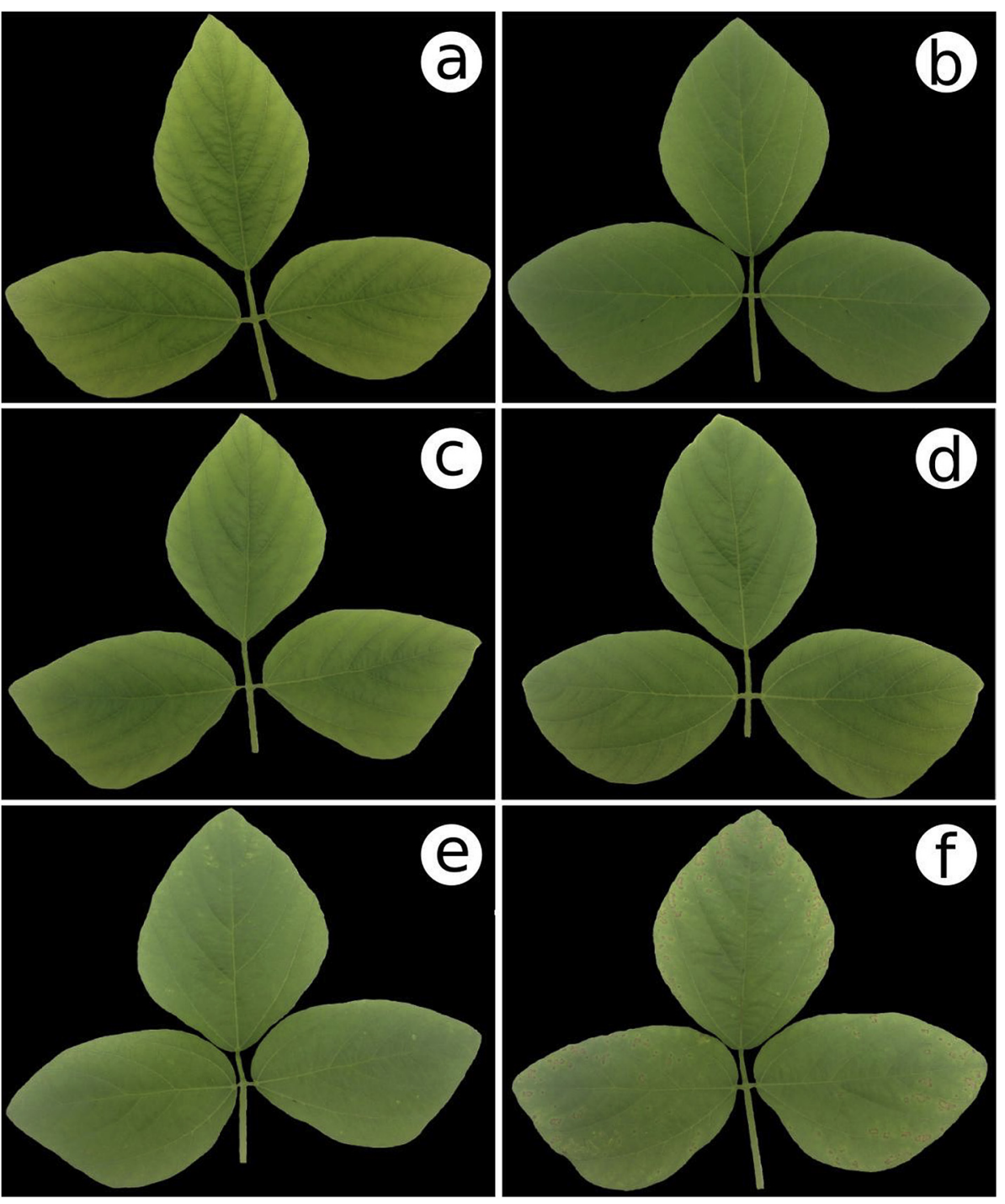

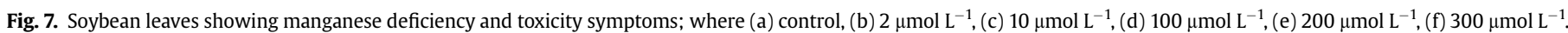
The leaves were harvested after 7 days of exposure to manganese treatments.

The deleterious effects of Mn toxicity on many species have mainly been studied considering the morphological, anatomical, ultrastructure, and biochemical aspects of the plant shoots, particularly where the toxic symptoms are manifested: the leaves. However, there is a lack of studies on the toxic effects of Mn in root cells (Santandrea et al., 1998; Lavres Junior et al., 2010). Santandrea et al. (1998) reported that plants tolerant to excess Mn (5000.0 $\mu \mathrm{mol} \mathrm{L}^{-1}$ ) exhibited a greater number of xylem elements (protoxylem and metaxylem) with lignified walls compared to plants of the control treatment $\left(100.0 \mu \mathrm{mol} \mathrm{L} \mathrm{L}^{-1}\right)$. They also concluded that in the control treatment, the roots exhibited only protoxylem elements.

An external manifestation of abnormality (visible symptoms) caused by the toxicity of a mineral element is the result of a chain of events where the final alteration is a subcellular modification, which leads to epidermal modifications and alterations (Lavres Junior et al., 2010). In the present study, an increase in roughness and cellular derangement was observed in the adaxial portions of the leaves at the highest $\mathrm{Mn}$ dose $\left(300 \mu \mathrm{mol} \mathrm{L} \mathrm{L}^{-1}\right)$, resulting in epidermal hypertrophying, i.e., a large disruption in the cellular arrangement (Fig. 10F). This epidermal hypertrophying is caused by thinning of the adaxial leaf epidermis in response to Mn toxicity, as observed in Fig. 6B.

The necrotic lesions on the leaves caused by Mn toxicity began to appear on the edges of the leaves (Fig. 7E), increasing in concentration as a result of increased $\mathrm{Mn}$ in the cultivation solution (Fig. 7F). Page et al. (2006) reported that the highest concentration of $\mathrm{Mn}$ occurs at the edges of the leaves because Mn participates in the leaf transpiration stream. Thus, lesions on the soybean leaves in the present study were observed on the leaf tissue of the plants submitted to the highest Mn concentration.

Excess $\mathrm{Mn}$ in the leaf tissues causes necrotic spots with dark purple-colored inclusions (Fig. 8), generally interpreted as a stress. Phytotoxicity of $\mathrm{Mn}$ is primarily mediated in the apoplast, causing callose and the formation of purple-colored necrotic regions (Fernando and Lynch, 2015). These purple-colored necrotic regions contain deposits of Mn oxides and oxidized phenols, and increase with POD activity in the apoplast (Wissemeier and Horst, 1992). Blamey et al. (2015) also found high concentrations of Mn (III) deposited in the part between the necrotic area and the healthy area of soybean leaves. Furthermore, Hughes and Williams (1988) concluded that Mn transporters in eukaryotic cells are practically 

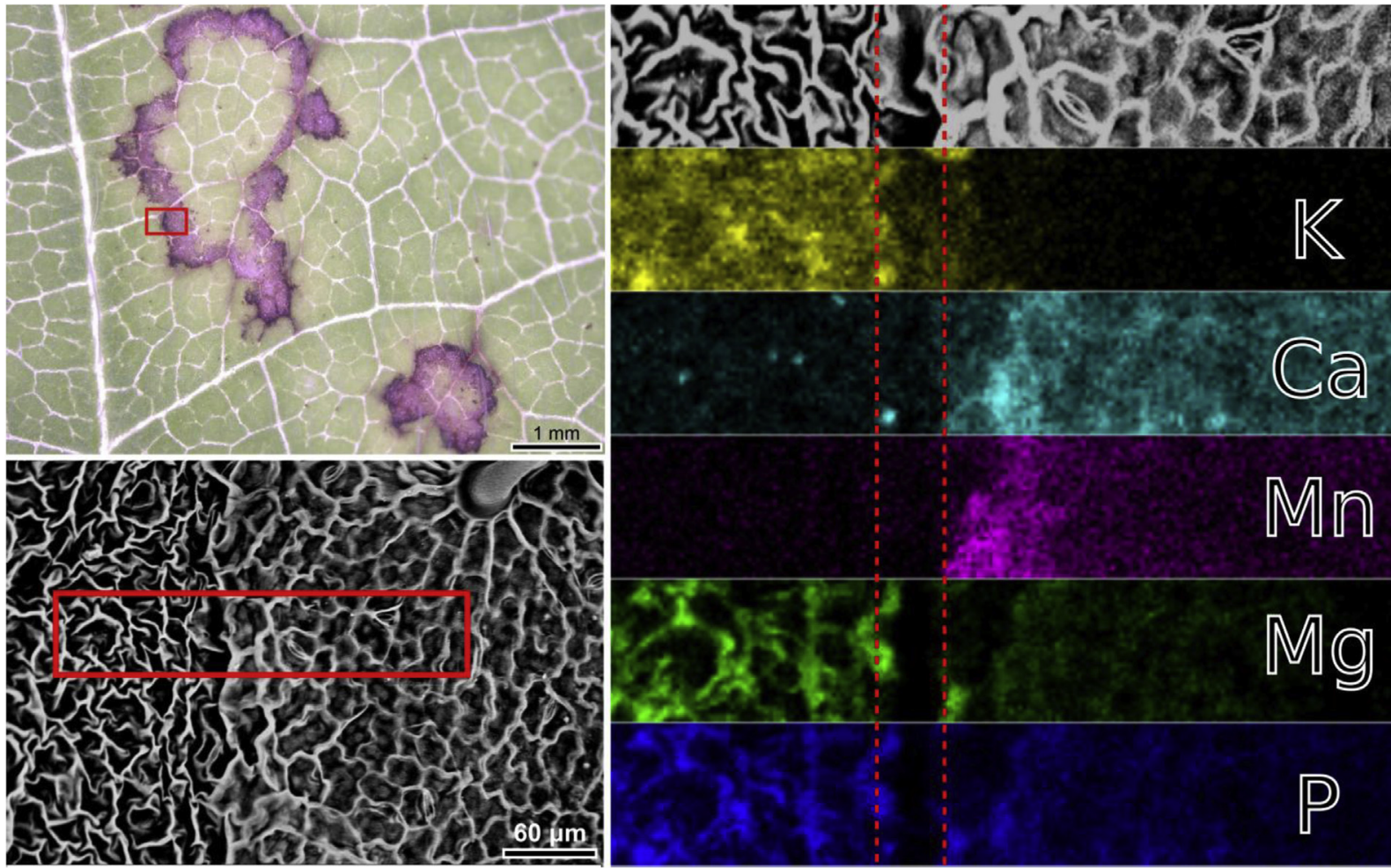

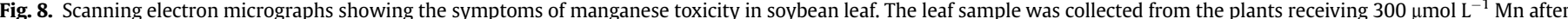

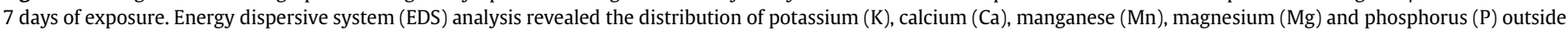
and inside the lesion area caused by manganese toxicity in soybean leaves.

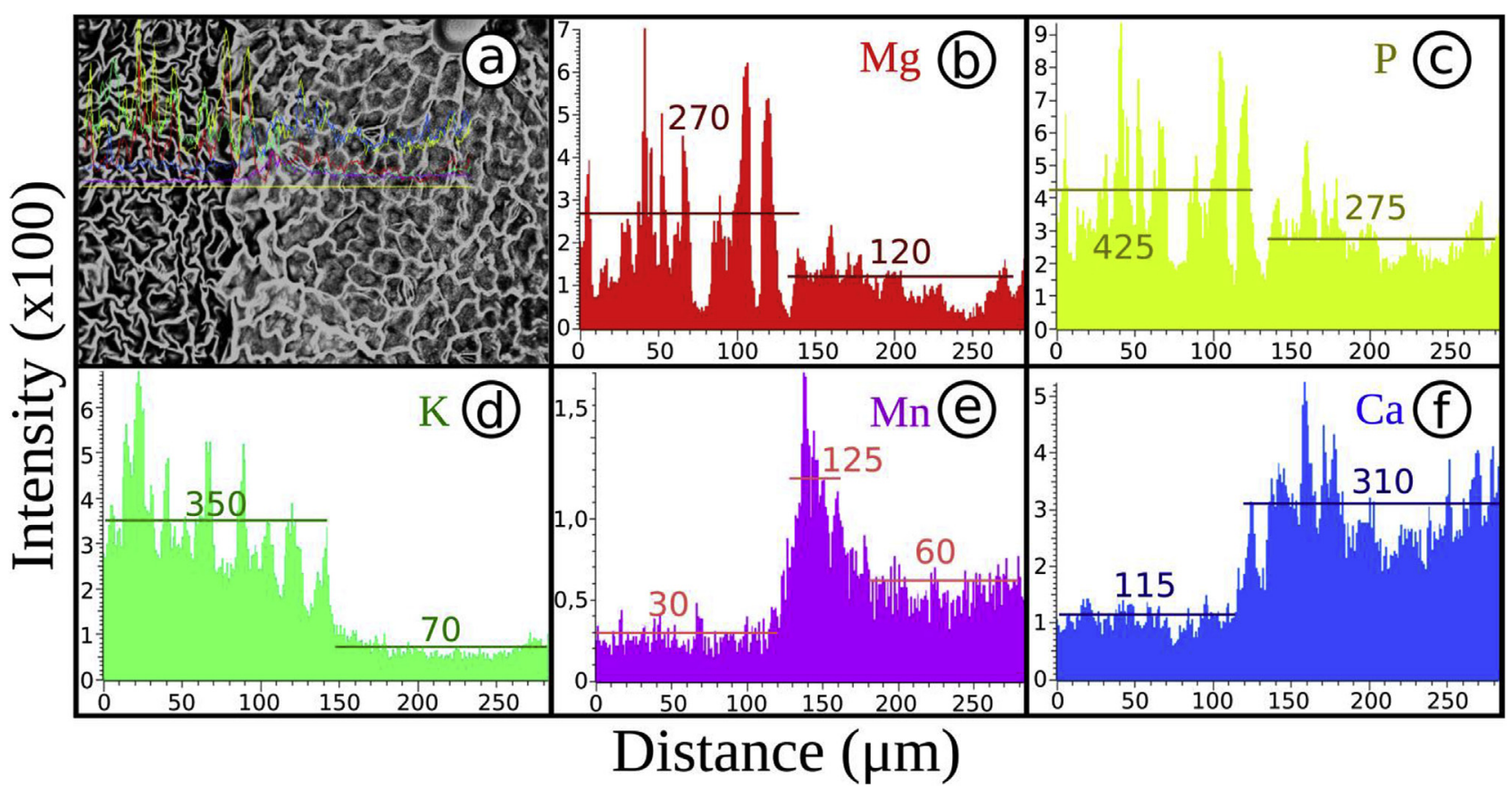

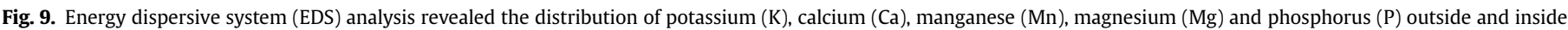

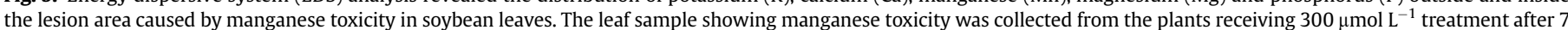
days of exposure.

in the vesicle portion of the cell instead of the cytoplasm, where the Mn concentration is toxic (Führs et al., 2009). High Mn concentrations in the veins (the region between the healthy part and the lesioned part) suggest the absence of an efficient Mn drain in soybean leaves. Excess $\mathrm{Mn}$ retained in cell walls of the internerval region causes necrosis from the oxidation of phenolic compounds 

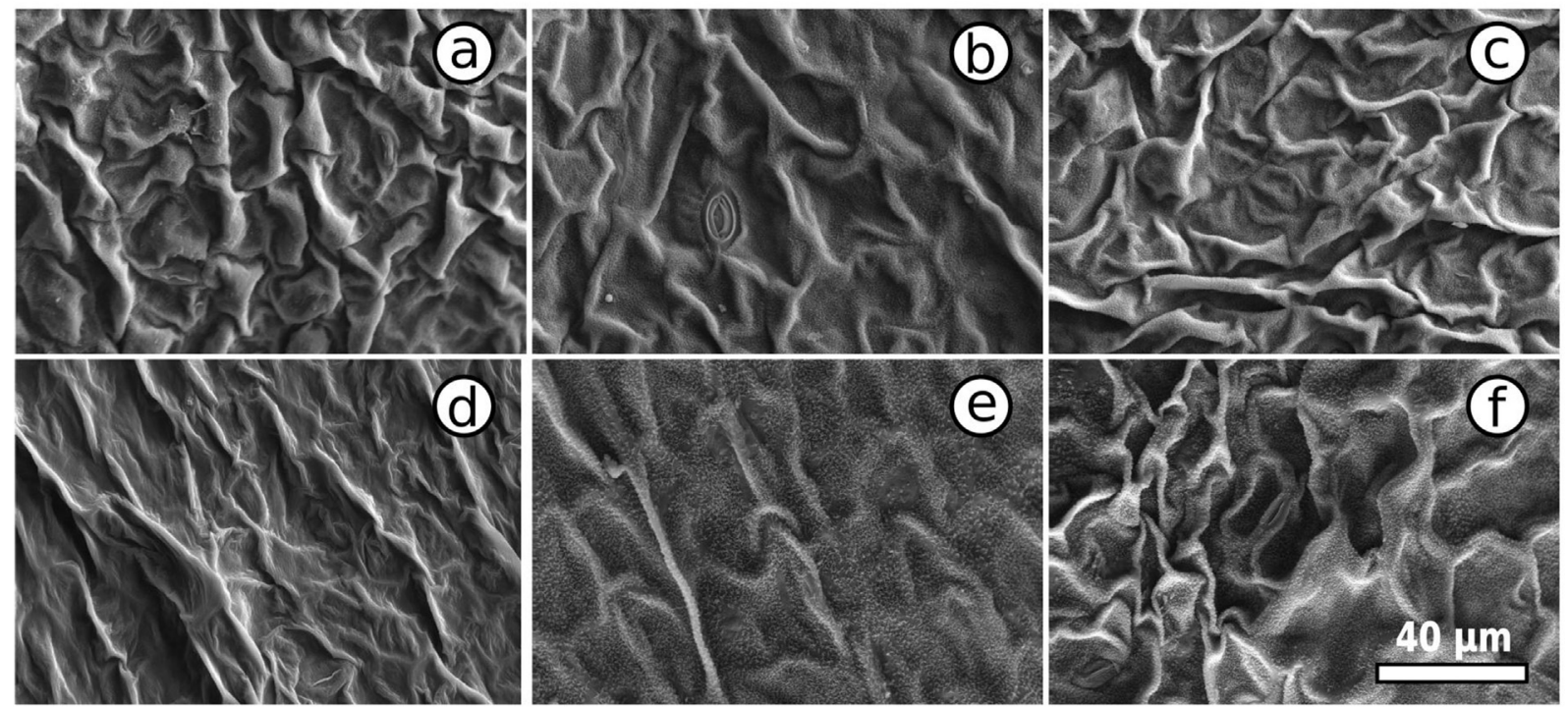

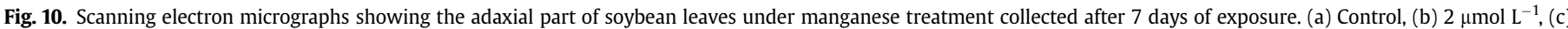
$10 \mu \mathrm{mol} \mathrm{L}^{-1}$, (d) $100 \mu \mathrm{mol} \mathrm{L}^{-1}$, (e) $200 \mu \mathrm{mol} \mathrm{L}^{-1}$, (f) $300 \mu \mathrm{mol} \mathrm{L}^{-1}$.
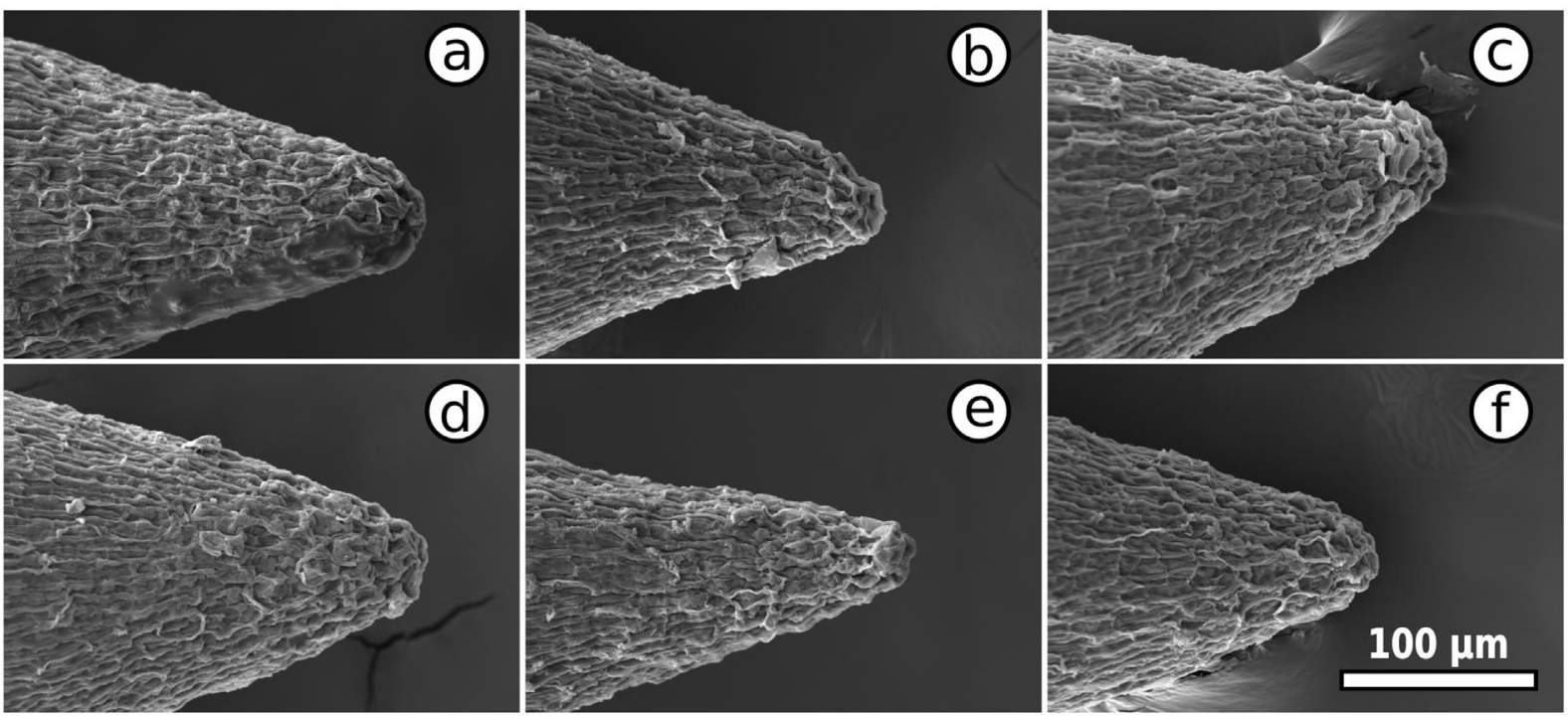

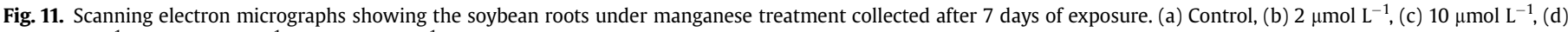
$100 \mu \mathrm{mol} \mathrm{L}^{-1}$, (e) $200 \mu \mathrm{mol} \mathrm{L}-1$, (f) $300 \mu \mathrm{mol} \mathrm{L}^{-1}$.

(Wissemeier et al., 1992) and the high activity of apoplastic POD (Horst et al., 1999). The oxidation of Mn (II) to Mn (III) can be a consequence of callose formation by cell injury (Blamey et al., 2015), causing the purple spots found on soybean leaves. The purple spots found on the leaves are the main symptoms of Mn toxicity (St. Clair et al., 2005). Other symptoms characteristic of toxicity include chlorosis and distorted leaves with small dark lesions (Blamey et al., 2015). These lesions were demonstrated with cowpea (Vigna unguiculata) containing oxidized $\mathrm{Mn}$ and callose (Wissemeier et al., 1992), which form through an intracellular reaction of elevated Ca contents (Kartusch, 2003). Further studies are necessary to elucidate the mechanism that causes the vacuolar difference of Mn and Ca in soybean leaves (Blamey et al., 2015).

Calcium was the only nutrient that presented higher concentrations in the lesion of the leaves with pronounced symptoms of Mn toxicity than in the tissue surrounding the lesion (Fig. 9), similar to that observed by Blamey et al. (2015) in soybean leaves. The necrotic lesions on the leaves of plants exposed to Mn toxicity have high concentrations of Mn oxide and callus formation (Wissemeier et al., 1992), which in turn increases the concentration of intracellular Ca in necrotic cells (Kartusch, 2003). The necrotic lesions result in phenolic compounds (Wissemeier and Horst, 1992) and increase POD activity in the apoplast (Horst et al., 1999).

\subsection{Concentration of macro and micronutrients}

Mn is absorbed in the form of Mn(II) by the roots, but the high Mn concentration in the shoot tissue generates antagonism with other similar ions (St. Clair and Lynch, 2004; St. Clair et al., 2005). Unlike the Mn toxicity response of some species (Millaleo et al., 2010; Ueno et al., 2015; Yao et al., 2015) and common to other heavy metals (Gratão et al., 2005), soybean plants concentrated Mn predominantly in the shoots of the plant (Fig. 13C). Thus, in this study, no reduction in Mn translocation from the root to the shoot 

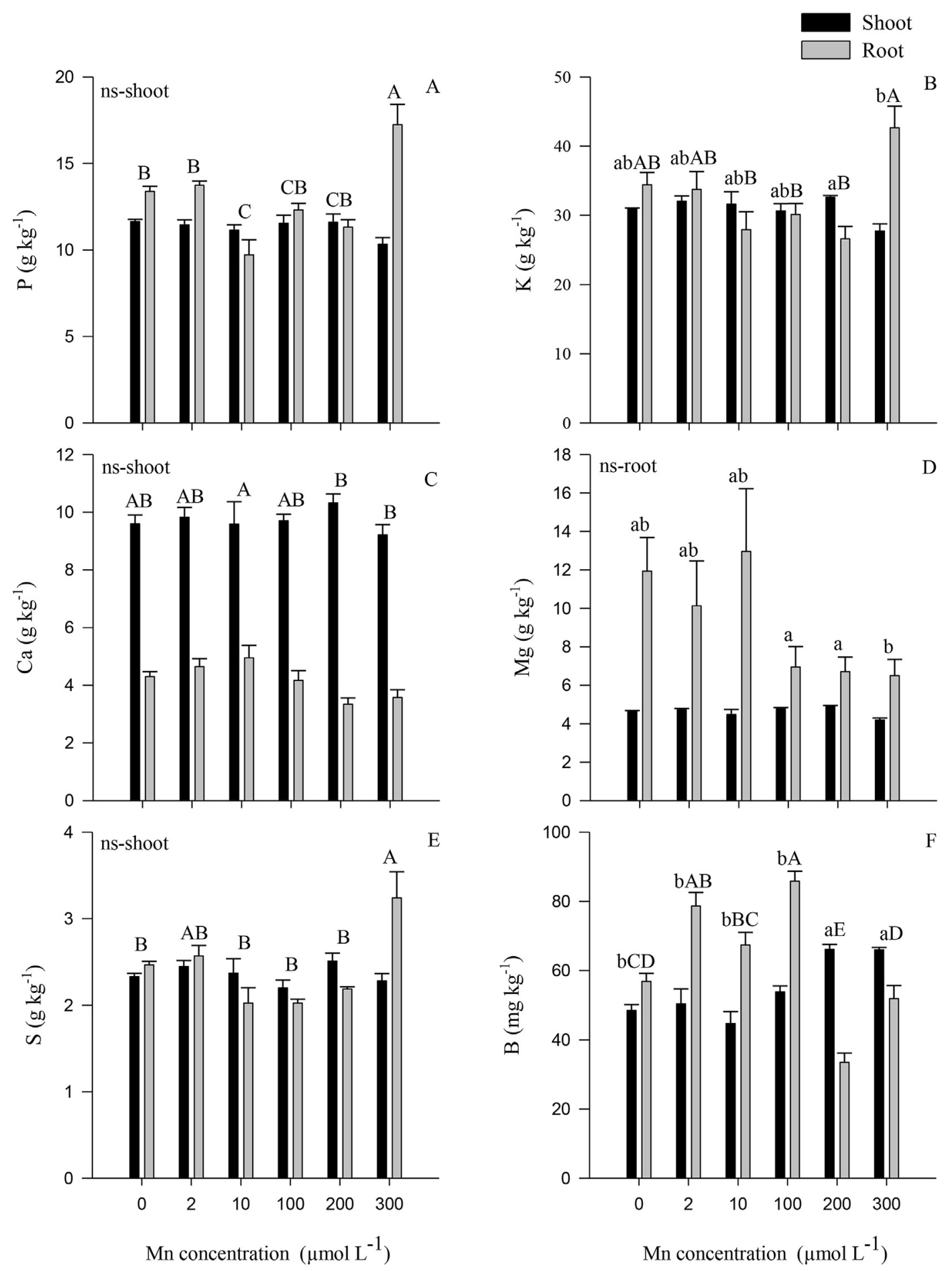

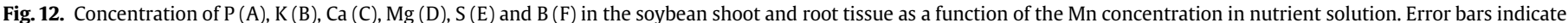

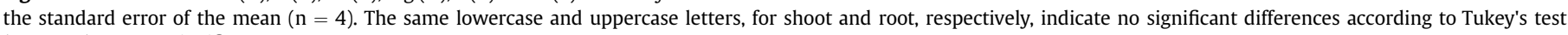
( $<<0.05)$. ns: not significant.

was observed. The first strategy of plants against the toxicity of metals is exclusion and complexation at the root (Gratão et al., 2005). The results of this study indicate that soybean has no regulation mechanisms for the absorption of $\mathrm{Mn}$ in toxic conditions, with the reduced expression of genes related to absorption and complexation of this element in grapes (Yao et al., 2015). Excess Mn can also cause stress by combined absorption with other ions such as Mg, Ca, K, and Fe (St. Clair and Lynch, 2005).
The Mn toxicity in plants is a nutritional disorder that is often not clearly identified. In turn, it can be the result of complex interactions of Mn with other elements (nutrients such as $\mathrm{K}, \mathrm{Ca}$, and Fe and beneficial element such as $\mathrm{Si}$ ) and some edaphic and climatic factors. The plant physiology response to excess metal accumulation depend on the plant growth rate, particularly the absolute growth rate of roots (Reis and Lavres Junior, 2011), cell size, and the vacuole, which is the main location of Mn accumulation. These 

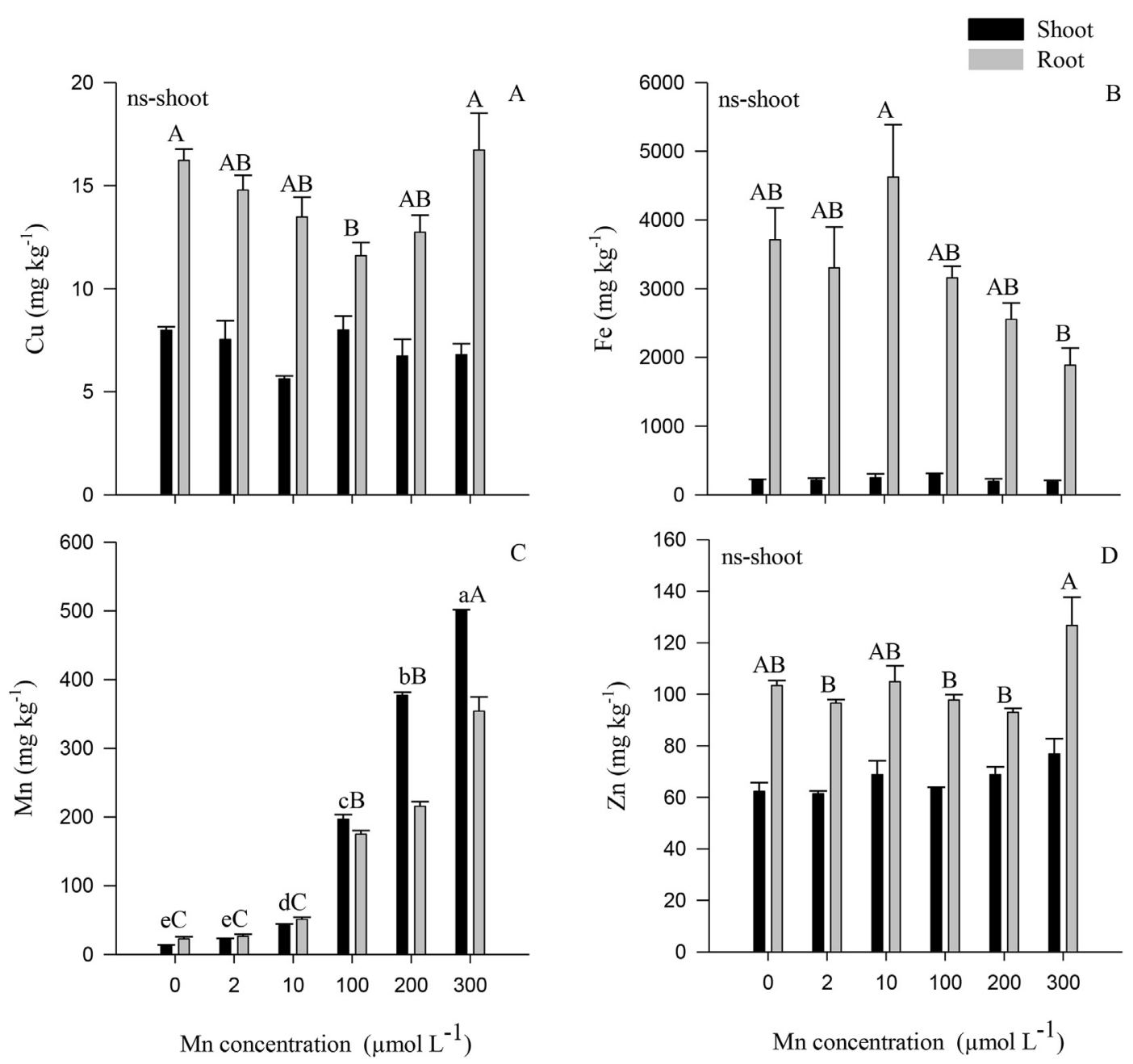

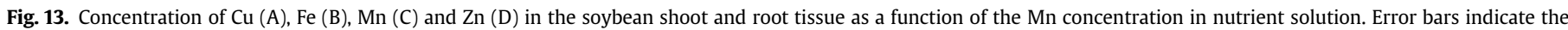

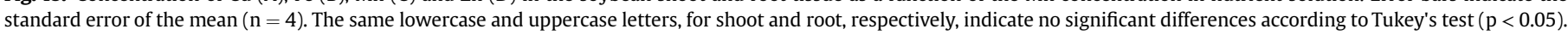
ns: not significant.

mechanisms, in turn, involve biochemical routes that differ significantly between species and varieties/cultivars. Mn toxicity is associated with increased root absorption, rapid transport to the shoot, and localized accumulation in the form of Mn oxide, resulting in brown spots on the leaves, as observed in the plants of this study. This abnormality is also attributed to the accumulation of phenolic compounds in the tissue, revealing coloration resulting from contact of the POD with easily oxidized substrates such as chlorogenic and caffeic acid, causing lower activity of antioxidant enzymes such as CAT, SOD, and POD, for example. Contrarily, in genotypes more tolerant to excessive or toxic quantities, there are reports of reductions in the quantities absorbed and transported over long distances and evidence of Mn toxic concentrations in the tissues. This Mn toxicity response is directly related to nutrition in $\mathrm{P}, \mathrm{K}, \mathrm{Ca}, \mathrm{Mg}$, or Fe, as well as more homogeneous distribution of $\mathrm{Mn}$ in the shoots (Lavres Junior et al., 2010).

\section{Conclusion}

The soybean plants showed symptoms of Mn toxicity at the doses of 200 and $300 \mu \mathrm{mol} \mathrm{L}{ }^{-1}$, reducing the photosynthetic rate and subsequently resulting in low dry mass yield. These Mn doses increased the activity of antioxidant enzymes such as CAT, POD, and SOD. The results of the present study enhance the understanding of several basic mechanisms of Mn toxicity in soybeans, which are still poorly understood, by describing the distribution of nutrients such as $\mathrm{K}, \mathrm{Ca}, \mathrm{Mn}, \mathrm{Mg}$, and $\mathrm{P}$ in the necrotic lesion caused by Mn toxicity. $\mathrm{Ca}$ and $\mathrm{Mn}$ are found exclusively in the lesion, $\mathrm{K}$ is outside the lesion, and $\mathrm{Mg}$ and $\mathrm{P}$ are in both regions, with the former at higher concentrations outside the lesion compared to inside the lesion.

\section{Contribution}

All authors contributed in the same way to the preparation of all the parts of this manuscript.

\section{References}

Aibibu, N., Liu, Y., Zeng, G., Wang, X., Chen, B., Song, H., Xu, L., 2010. Cadmium accumulation in Vetiveria zizanioides and its effects on growth, physiological and biochemical characters. Bioresour. Technol. 101, 6297-6303.

Allain, C.C., Poon, L.S., Chan, C.S., Richmond, W., Fu, P.C., 1974. Enzymatic determination of total serum cholesterol. Clin. Chem. 20, 470-475.

Azevedo, R.A., Alas, R.M., Smith, R.J., Lea, P.J., 1998. Response of antioxidant enzymes to transfer from elevated carbon dioxide to air and ozone fumigation, in the leaves and roots of wild-type and a catalase-deficient mutant of barley. Physiol. Plant. 104, 280-292.

Blamey, P., Hernandez-Soriano, M., Cheng, M., Tang, C., Paterson, D., Lombi, E., Wang, W.H., Scheckel, K., Kopittke, P.M., 2015. Synchrotron-based techniques shed light on mechanisms of plant sensitivity and tolerance to high manganese in the root environment. Plant Physiol. 169, 2006-2020. 
Bradford, M.M., 1976. A rapid and sensitive method for the quantitation of microgram quantities of protein utilizing the principle of protein-dye binding. Anal. Biochem. 72, 248-254.

Carlquist, S.J., 1975. Ecological Strategies of Xylem Evolution. University of California Press, Berkley CA.

Chen, Z., Yan, W., Sun, L., Tian, J., Liao, H., 2016. Proteomic analysis reveals growth inhibition of soybean roots by manganese toxicity is associated with alteration of cell wall structure and lignification. J. Proteomics 143, 151-160.

Choudhary, S.P., Yu, J.Q., Yamaguchi-Shinozaki, K., Shinozaki, K., Tran, L.-P., 2012 Benefits of brassinosteroid crosstalk. Trends Plant Sci. 17, 594-605.

Ducic, T., Polle, A., 2005. Transport and detoxification of manganese and copper in plants. Braz. J. Plant Physiology 17, 103-112.

Fageria, N.K., Stone, L.F., 2008. Micronutrient deficiency problems in South America. In: Alloway, B.J. (Ed.), Micronutrient Deficiencies in Global Crop Production. Springer, Dordrecht, pp. 245-266.

Fehr, W.E., Caviniss, C.E., Burmood, D.T., Pennington, J.S., 1971. Stage of development descriptions for soybeans, Glycine max (L.) Merrill. Crop Sci. 11, 929-931.

Fernando, D.R., Lynch, J.P., 2015. Manganese phytotoxicity: new light on an old problem. Ann. Bot. 116, 313-319.

Fernando, D.R., Marshall, A.T., Forster, P.I., Hoebee, S.E., Siegele, R., 2013. Multiple metal accumulation within a manganese-specific genus. Am. J. Bot. 100, $690-700$.

Fischer, W.W., Hemp, J., Johnson, J.E., 2015. Manganese and the evolution of photosynthesis. Orig. Life Evol. Biospheres 45, 351-357.

Foyer, C.H., Shigeoka, S., 2011. Understanding oxidative stress and antioxidant functions to enhance photosynthesis. Plant Physiol. 155, 93-100.

Führs, H., Gotze, S., Specht, A., Erban, A., Gallien, S., Heintz, D., Van Dorsselaer, A Kopka, J., Braun, H.P., Horst, W.J., 2009. Characterization of leaf apoplastic peroxidases and metabolites in Vigna unguiculata in response to toxic manganese supply and silicon. J. Exp. Bot. 60, 1663-1678.

Giannopolitis, C.N., Ries, S.K., 1977. Superoxide dismutases: I. Occurrence in higher plants. Plant Physiol. 59, 309-314.

Gill, S.S., Tuteja, N., 2010. Reactive oxygen species and antioxidant machinery in abiotic stress tolerance in crop plants. Plant Physiology Biochem. 48, 909-930.

Gratão, P.L., Polle, A., Lea, P.J., Azevedo, R.A., 2005. Making the life of heavy metalstressed plants a little easier. Funct. Plant Biol. 32, 481-494.

Gratão, P.L., Monteiro, C.C., Rossi, M.L., Martinelli, A.P., Peres, L.E.P., Medici, L.O., Lea, P.J., Azevedo, R.A., 2009. Differential ultrastructural changes in tomato hormonal mutants exposed to cadmium. Environ. Exp. Bot. 67, 387-394.

Gururani, M.A., Venkatesh, J., Tran, L.S.P., 2015. Regulation of photosynthesis during abiotic stress-induced photoinhibition. Mol. Plant 8, 1304-1320.

Gustafsson, J.P., 2011. Visual MINTEQ Ver. 3.0. KTH, department of land and water resources engineering. http://www2.lwr.kth.se/English/OurSoftware/vminteq/.

Hoagland, D.R. Arnon, D.I., 1950. The water-culture method for growing plants without soil. California agricultural experiment station circular 347. In: College of Agriculture. University of California, Berkeley.

Hogan, M.E., Swift, I.E., Done, J., 1983. Urease assay and ammonia release from leaf tissues. Phytochemistry 22, 663-667.

Horst, W.J., Fecht, M., Naumann, A., Wissemeier, A.H., Maier, P., 1999. Physiology of manganese toxicity and tolerance in Vigna unguiculata (L.) walp. J. Plant Nutr Soil Sci. 162, 263-274.

Hughes, N.P., Williams, R.J.P., 1988. An introduction to manganese biological chemistry. In: Graham, R.D., Hannam, R.J., Uren, N.C. (Eds.), Manganese in Soils and Plants. Kluwer Academic Publishers, Dordrecht, Netherlands, pp. 7-19.

Jiang, H., Xu, D.Q., 2001. The cause of the difference in leaf net photosynthetic rate between two soybean cultivars. Photosynthetica 39, 453-459.

Kartusch, R., 2003. On the mechanism of callose synthesis induction by metal ions in onion epidermal cells. Protoplasma 220, 219-225.

Kato, Y., Sakamoto, W., 2014. Phosphorylation of photosystem II core proteins prevents undesirable cleavage of D1 and contributes to the fine-tuned repair of photosystem II. Plant J. 79, 312-321.

Kochian, L.V., Hoekenga, O.A., Piñeros, M.A., 2004. How do crop plants tolerate acid soils? Mechanisms of aluminum tolerance and phosphorous efficiency. Annu. Rev. Plant Biol. 55, 459-493.

Lavres Junior, J., Reis, A.R., Rossi, M.L., Cabral, C.P., Nogueira, N.L., Malavolta, E., 2010. Changes in the ultrastructure of soybean cultivars in response to manganese supply in solution culture. Sci. Agric. 67, 287-294.

Le, D.T., Nishiyama, R., Watanabe, Y., Vankova, R., Tanaka, M., Seki, M., Ham, L.H. Yamaguchi-Shinozaki, K., Shinozaki, K., Tran, L.S.P., 2012. Identification and expression analysis of cytokinin metabolic genes in soybean under normal and drought conditions in relation to cytokinin levels. PLoS One 7, e42411.

Lidon, F.C., 2002. Rice plant structural changes by addition of excess manganese J. Plant Nutr. 25, 287-296.

McCullough, H., 1967. The determination of ammonia in whole blood by a direct colorimetric method. Clin. Chim. Acta 17, 297-304.

Merlin, T.P.A. Lima, G.P.P. Leonel, S., Vianello, F. 2012. Peroxidase activity and total phenol content in citrus cuttings treated with different copper sources. South Afr. J. Bot. 83, 159-164.

Millaleo, R., Reyes-Diaz, M., Ivanov, A.G., Mora, M.L., Alberdi, M., 2010. Manganese as essential and toxic element for plants: transport, accumulation and resistance mechanisms. J. Soil Sci. Plant Nutr. 10, 470-481.

Millaleo, R., Reyes-Diaz, M., Alberdi, M., Ivanov, A.G., Krol, M., Huner, N.P., 2013. Excess manganese differentially inhibits photosystem I versus II in Arabidopsis thaliana. J. Exp. Bot. 64, 343-354.

Miller, R.O., 1998. Nitric-perchloric acid wet digestion in an open vessel. In: Karla, Y.P. (Ed.), Handbook of Reference Methods for Plant Analysis. CRC Press, Boca Raton, FL, pp. 57-61.

Nishiyama, Y., Allakhverdiev, S.I., Murata, N., 2011. Protein synthesis is the primary target of reactive oxygen species in the photoinhibition of photosystem II. Physiol. Plant. 142, 35-46.

Noctor, G., Gomez, L., Vanacker, H., Foyer, C.H., 2002. Interactions between biosynthesis, compartmentation and transport in the control of glutathione homeostasis and signalling. J. Exp. Bot. 53, 1283-1304.

Page, V., Bayon, R.-C.L., Feller, U., 2006. Partitioning of zinc, cadmium, manganese and cobalt in wheat (Triticum aestivum) and lupin (Lupinus albus) and further release into the soil. Environ. Exp. Bot. 58, 269-278.

Reis, A.R., Lavres Junior, J., 2011. Genotypic influence on the absorption, use and toxicity of manganese by soybean. In: Sudaric, A. (Ed.), Soybean - Molecular Aspects of Breeding. Intech Publisher, Croatia, pp. 241-258.

Reis, A.R., Favarin, J.L., Gallo, L.A., Malavolta, E., Moraes, M.F., Lavres Junior, J., 2009. Nitrate reductase and glutamine synthetase activity in coffee leaves during fruit development. Rev. Bras. Ciência do Solo 33, 315-324.

Reis, A.R., Favarin, J.L., Gratão, P.L., Capaldi, F.R., Azevedo, R.A., 2015. Antioxidant metabolism in coffee (Coffea arabica L.) plants in response to nitrogen supply. Theor. Exp. Plant Physiology 27, 203-213.

Rojas-Lillo, Y., Alberdi, M., Acevedo, P., Inostroza-Blancheteau, C., Rengel, Z., Mora, M.D.L.L., Reyes-Díaz, M., 2014. Manganese toxicity and UV-B radiation differentially influence the physiology and biochemistry of highbush blueberry (Vaccinium corymbosum) cultivars. Funct. Plant Biol. 41, 156-167.

Santandrea, G., Schiff, S., Bennici, A., 1998. Effects of manganese on nicotiana species cultivated in vitro and characterization of regenerated Mn-tolerant tobacco plants. Plant Sci. 132, 71-82.

Schmutz, J., Cannon, S.B., Schlueter, J., et al., 2010. Genome sequence of the palaeopolyploid soybean. Nature 463, 178-183.

Schutzendubel, A., Polle, A., 2002. Plant responses to abiotic stresses: heavy metalinduced oxidative stress and protection by mycorrhization. J. Exp. Bot. 53, 1351-1365.

Shuai, X., 2016. Two-dimensional segmented regression model for aluminum and manganese toxicity and their interaction in soybean. Agron. J. 108, 1041-1049.

St Clair, S.B., Lynch, J.P., 2004. Photosynthetic and antioxidant enzyme responses of sugar maple and red maple seedlings to excess manganese in contrasting light environments. Funct. Plant Biol. 31, 1005-1014.

St Clair, S.B., Lynch, J.P., 2005. Element accumulation patterns of deciduous and evergreen tree seedlings on acid soils: implications for sensitivity to manganese toxicity. Tree Physiol. 25, 85-92.

St Clair, S.B., Carlson, J.E., Lynch, J.P., 2005. Evidence for oxidative stress in sugar maple stands growing on acidic, nutrient imbalanced forest soils. Oecologia $145,257-268$

Toth, S.Z., Nagy, V., Puthur, J.T., Kovacs, L., Garab, G., 2011. The physiological role of ascorbate as photosystem ii electron donor: protection against photoinactivation in heat-stressed leaves. Plant Physiol. 156, 382-392.

Ueno, D., Sasaki, A., Yamaji, N., et al., 2015. A polarly localized transporter for efficient manganese uptake in rice. Nat. Plants 1,15170.

Weng, X.Y., Zhao, L.L., Zheng, C.J., Zhu, J.W., 2013. Characteristics of the hyperaccumulator plant Phytolacca acinosa (phytolaccaceae) in response to excess manganese. J. Plant Nutr. 36, 1355-1365.

Wissemeier, A.H., Horst, W.J., 1992. Effect of light intensity on manganese toxicity symptoms and callose formation in cowpea (Vigna unguiculata (L.) walp.). Plant Soil 143, 299-309.

Wissemeier, A.H., Diening, A., Hergenroder, A., Horst, W.J., Mix-Wagner, G., 1992. Callose formation as parameter for assessing genotypical plant tolerance of aluminium and manganese. Plant Soil 146, 67-75.

Yao, Y., Xiao, X., Ou, Y., Wu, X., Xu, G., 2015. Root transcriptome analysis on the grape genotypes with contrast translocation pattern of excess manganese from root to shoot. Plant Soil 387, 49-67.

Zambrosi, F.C.B., Mesquita, G.L., Marchiori, P.E.R., Tanaka, F.A.O., Machado, E.C. Ribeiro, R.V., 2016. Anatomical and physiological bases of sugarcane tolerance to manganese toxicity. Environ. Exp. Bot. 132, 100-112. 